\title{
Article \\ Tethered Blatter Radical for Molecular Grafting: Synthesis of 6-Hydroxyhexyloxy, Hydroxymethyl, and Bis(hydroxymethyl) Derivatives and Their Functionalization ${ }^{\dagger}$
}

\author{
Szymon Kapuściński ${ }^{1,2}$ D , Bindushree Anand ${ }^{2}$, Paulina Bartos ${ }^{1}$, Jose M. Garcia Fernandez ${ }^{3, * \mathbb{D}}$ \\ and Piotr Kaszyński 1,2,4,*(D) \\ 1 Faculty of Chemistry, University of Łódź, Tamka 12, 91-403 Łódź, Poland; szymkap@gmail.com (S.K.); \\ paulina.bartos@chemia.uni.lodz.pl (P.B.) \\ 2 Centre for Molecular and Macromolecular Studies, Polish Academy of Sciences, Sienkiewicza 112, \\ 90-363 Łódź, Poland; bindushreearadhya93@gmail.com \\ 3 Institute for Chemical Research, CSIC, University of Sevilla, Americo Vespucio 49, 41092 Sevilla, Spain \\ 4 Department of Chemistry, Middle Tennessee State University, Murfreesboro, TN 37132, USA \\ * Correspondence: jogarcia@iiq.csic.es (J.M.G.F.); piotr.kaszynski@chemia.uni.lodz.pl (P.K.) \\ $\dagger$ Dedicated to Professor Mieczysław Mąkosza.
}

check for

updates

Citation: Kapuściński, S.; Anand, B.;

Bartos, P.; Garcia Fernandez, J.M.; Kaszyński, P. Tethered Blatter Radical for Molecular Grafting: Synthesis of 6-Hydroxyhexyloxy, Hydroxymethyl, and Bis(hydroxymethyl) Derivatives and Their Functionalization.

Molecules 2022, 27, 1176. https:// doi.org/10.3390/molecules27041176

Academic Editor: Rafał Loska

Received: 13 January 2022

Accepted: 1 February 2022

Published: 9 February 2022

Publisher's Note: MDPI stays neutral with regard to jurisdictional claims in published maps and institutional affiliations.

Copyright: (c) 2022 by the authors. Licensee MDPI, Basel, Switzerland. This article is an open access article distributed under the terms and conditions of the Creative Commons Attribution (CC BY) license (https:/ / creativecommons.org/licenses/by/ $4.0 /)$.

\begin{abstract}
Synthetic access to 7- $\mathrm{CF}_{3}-1,4-$ dihydrobenzo[ $[e][1,2,4]$ triazin-4-yl radicals containing 4-(6hydroxyhexyloxy)phenyl, 4-hydroxymethylphenyl or 3,5-bis(hydroxymethyl)phenyl groups at the $\mathrm{C}(3)$ position and their conversion to tosylates and phosphates are described. The tosylates were used to obtain disulfides and an azide with good yields. The Blatter radical containing the azido group underwent a copper(I)-catalyzed azide-alkyne cycloaddition with phenylacetylene under mild conditions, giving the $[1,2,3]$ triazole product in $84 \%$ yield. This indicates the suitability of the azido derivative for grafting Blatter radical onto other molecular objects via the CuAAC "click" reaction. The presented derivatives are promising for accessing surfaces and macromolecules spin-labeled with the Blatter radical.
\end{abstract}

Keywords: heterocycles; stable radicals; functional group transformation; azide-alkyne "click" reaction

\section{Introduction}

Functionalization of flat surfaces [1-9], polymers [10-14], well-defined macromolecules (dendrimers [15-18], cyclodextrins [19-22], fullerene [23], and nanotubes [24]), and nanoparticles [25-30] with stable radicals is becoming an important avenue for obtaining materials [31,32] for advanced technologies [33], which include organic electronics [11,34], spintronics $[1,3,6]$, contrast agents in bioimaging $[15,35,36]$, and energy storage [12,37-39]. This effort has concentrated mainly on the traditional stable radicals, such as nitroxides [6,14-19,32], tris(2,4,6,-trichlorophenyl)methyl (TTM) [7,9], and verdazyl [40], while the exploration of 1,4-dihydrobenzo[e][1,2,4]triazin-4-yls (so-called Blatter radicals) as active components of these materials began only recently and is rapidly intensifying.

Radicals have been chemisorbed onto an Au surface using the SR [1,2,6,26,41] and $\mathrm{C} \equiv \mathrm{CH}[7,42]$ groups, and the latter was used to graft radicals onto reduced Si surfaces [42]. Chemisorption of radicals and typical organic molecules onto other surfaces has been accomplished using $\mathrm{PO}(\mathrm{OR})_{2}$ groups (metal oxide substrates, e.g., $\mathrm{Fe}_{3} \mathrm{O}_{4}$ [25] and $\mathrm{LSMO}$ [6]), $\mathrm{COOH}$ group (GaAs) [43] and siloxanes (for $\mathrm{SiO}_{\mathrm{x}}$ and indium tin oxide-ITO-substrates) [44] Grafting of radicals onto macromolecules has been achieved using a variety of acylation and condensation reactions $[15-18,35,45,46]$. One of the most efficient grafting methods involves the $\mathrm{Cu}(\mathrm{I})$-catalyzed [3+2] cycloaddition ("click") reaction between an azide and a terminal alkyne, leading to the formation of the $[1,2,3]$ triazole ring with the 1,4-substitution pattern [47-49]. This approach has been applied to grafting ethynyl-containing radicals into systems with pending azido groups $[24,25,29,50]$. It should be added that radical polymers 
have also been obtained by polymerization of monomers containing stable radicals using, e.g., Rh catalysts, ring opening metathesis polymerization (ROMP), and electropolymerization methods $[13,14,40]$.

The 1,4-dihydrobenzo[e][1,2,4]triazin-4-yls [33,51], formal derivatives of the prototypical 1,3-diphenyl derivative known as the Blatter radical [52] A (Figure 1), are exceptionally stable, $\pi$-delocalized radicals characterized by favorable redox behavior with a narrow electrochemical window $(\sim 1.2 \mathrm{~V})[37,38]$ and a broad absorption in the visible range [53]. The stability of Blatter radical $\mathbf{A}$ is further enhanced by placing the $\mathrm{CF}_{3}$ group in the $\mathrm{C}(7)$ position leading to derivative $\mathbf{B}$, the so-called "super stable" radical [54]. For these reasons, 1,4-dihydrobenzo[e][1,2,4]triazin-4-yls are promising paramagnetic structural elements of functional materials [33], and have been explored as photoconductive liquid crystals [55-57], sensors [58], photodetectors [59], and also in spintronics [41,60,61].

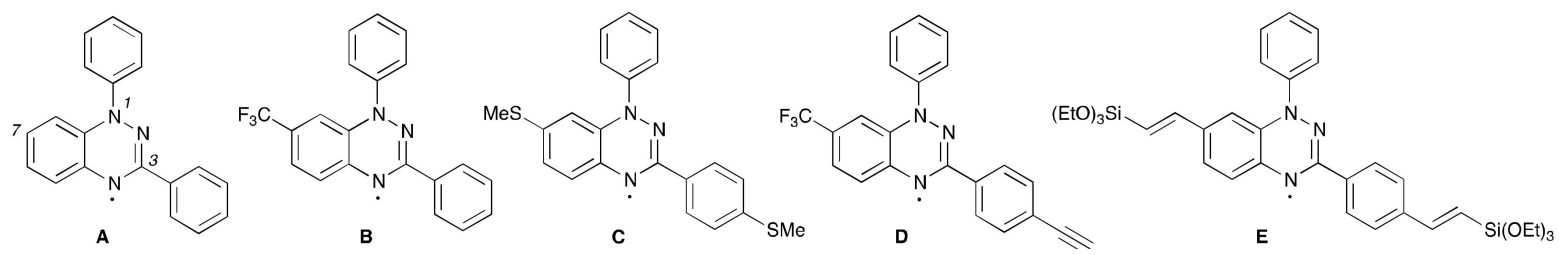

Figure 1. The structure of the prototypical Blatter radical (A), the "super stable" derivative (B), and functional derivatives (C-E).

There are still relatively few studies on Blatter radicals chemisorbed on surfaces or grafted on macromolecules, mainly due to insufficiently developed access to derivatives with appropriate functional groups. For instance, Blatter radical containing two Auanchoring SMe groups (C, Figure 1) was chemisorbed on the $\mathrm{Au}(111)$ surface and the interactions of the resulting molecular films with the surface were investigated in detail [41]. Acetylene derivative $\mathbf{D}$ was prepared and reacted with an azidonorbornene derivative under the "click" reaction conditions to give a norbornene-containing monomer, which was polymerized using the ROMP method. The acetylene derivative $\mathbf{D}$ could also be used for chemisorption onto the Au surface. Finally, bis(triethoxysilyl) derivative $\mathbf{E}$ was used for grafting the Blatter radical onto mesoporous silica [62] and could also be used for the functionalization of $\mathrm{Si}$ and metal surfaces with native oxides.

Despite progress in functional derivatives of the Blatter radical, there is a need to broaden the range of intermediates containing active functionalities for grafting onto diverse types of surfaces and macromolecules.

Herein we describe three derivatives of the "super stable" Blatter radical containing the 6-hydroxyhexyloxy (Ia, Figure 2) or hydroxymethyl (IIa and IIIa) substituents on the $\mathrm{C}(3)-\mathrm{Ph}$ ring as key intermediates to functional derivatives suitable for grafting onto low dimensional systems. We report a conversion of the alcohols Ia-IIIa to the corresponding tosylates Ib-IIIb and phosphates Ic and IIc, and transformations of the tosylates to disulfides Id and IId, and azide Ie. As a proof of concept, we demonstrate the "click" reaction of azide Ie with an alkyne.

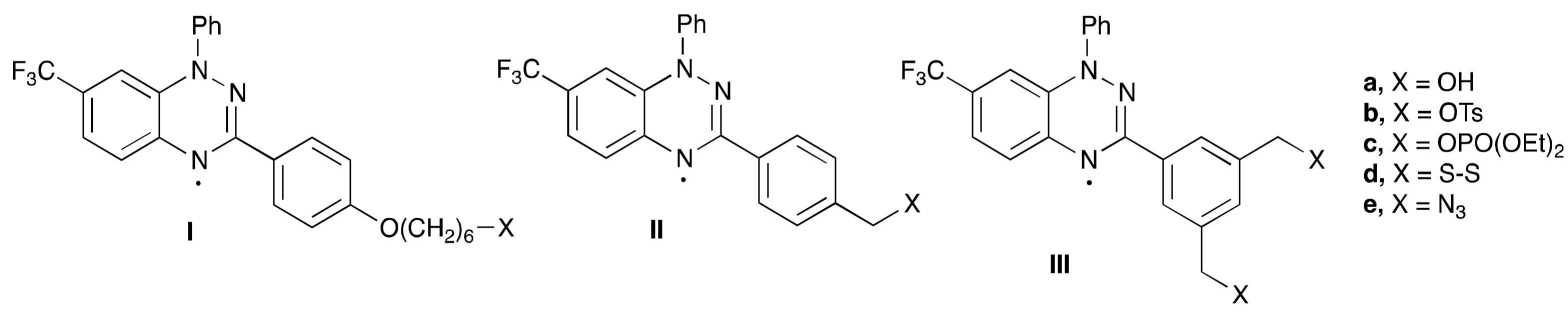

Figure 2. The structure of three types of radicals (I-III) for molecular grafting. Reported compounds: Ia-Ie, IIa-IId, IIIa and IIIb. 


\section{Results and Discussion}

\subsection{Synthesis of Hydroxyl Derivatives Ia-IIIa}

Radicals Ia-IIIa containing versatile hydroxyl groups were prepared using the recently discovered regioselective azaphilic addition of aryllithium to benzo[ $e][1,2,4]$ triazines [63] Thus, phenyllithium was reacted with benzo[e][1,2,4] triazines 1-3, and the resulting anions were oxidized with air to the corresponding radicals Ia-IIIa, which were conveniently isolated by column chromatography $\left(\mathrm{SiO}_{2}\right.$ support) in yields up to $92 \%$ (Scheme 1$)$. It should be noted that both hydroxy (1 and $\mathbf{3})$ and acetoxy (2) derivatives were suitable starting materials for this reaction affording the corresponding radicals in comparable yields. The route to Ia involving addition of phenyllithium to compound 4, the O-benzyl protected alcohol 1 (Scheme 2), followed by Pd-catalyzed reductive debenzylation of the resulting radical If (Scheme 1) turned out to be inefficient. While the PhLi addition and formation of If worked well (yield up to $64 \%$, Scheme 2), debenzylation of If gave only decomposition products. This presumably resulted from the more vigorous conditions needed for the removal of the O-benzyl group in the alkyl benzyl ethers than in the aryl analogues.

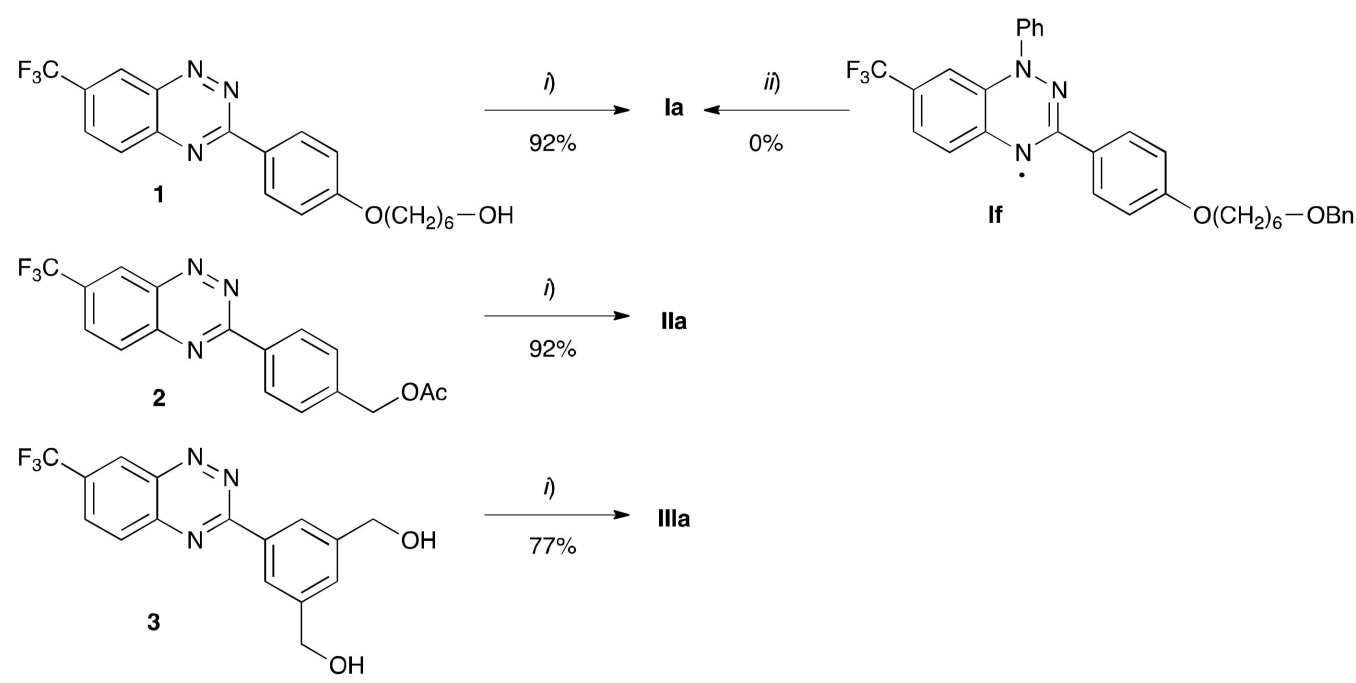

Scheme 1. Synthesis of radicals (Ia-IIIa). Reagents and conditions: (i) $1 . \mathrm{PhLi}, \mathrm{THF}, \mathrm{Ar},-5{ }^{\circ} \mathrm{C}, 1 \mathrm{~h}$; 2. Air, 0.5 h, 77-92\% yield; (ii) 1 . Pd/C, $\mathrm{H}_{2}, 50$ psi, THF/EtOH, 2 days, 2. Air, $0 \%$ yield.<smiles>[X]c1cc(C(=O)NN)cc([X])c1[X]</smiles><smiles>C[13CH2][13CH3]</smiles><smiles>Nc1cc(C(F)(F)F)ccc1[N+](=O)[O-]</smiles><smiles>[X]c1cc(C(N)=O)cc([X])c1[X]</smiles>

8, $\mathrm{Y}=\mathrm{H}, \mathrm{X}=\mathrm{O}\left(\mathrm{CH}_{2}\right)_{6} \mathrm{OBn}$ 9, $\mathrm{Y}=\mathrm{H}, \mathrm{X}=\mathrm{CH}_{2} \mathrm{OH}$

10, $\mathrm{X}=\mathrm{H}, \mathrm{Y}=\mathrm{CH}_{2} \mathrm{OH}$

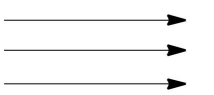

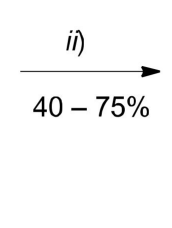<smiles>[Y]c1cc(-c2nnc3cc(C(F)(F)F)ccc3n2)cc([X])c1[X]</smiles>

1, $\mathrm{Y}=\mathrm{H}, \mathrm{X}=\mathrm{O}\left(\mathrm{CH}_{2}\right)_{6} \mathrm{OH}$

4, $\left.\mathrm{Y}=\mathrm{H}, \mathrm{X}=\mathrm{O}\left(\mathrm{CH}_{2}\right)_{6} \mathrm{OBn}\right)$ iii) $31 \%$

5, $\mathrm{Y}=\mathrm{H}, \mathrm{X}=\mathrm{O}\left(\mathrm{CH}_{2}\right)_{6} \mathrm{OB}$ 6, $\mathrm{Y}=\mathrm{H}, \mathrm{X}=\mathrm{CH}_{2} \mathrm{OH}$ 7, $\mathrm{X}=\mathrm{H}, \mathrm{Y}=\mathrm{CH}_{2} \mathrm{OH}$

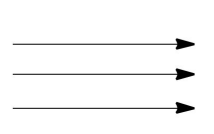

2, $\mathrm{Y}=\mathrm{H}, \mathrm{X}=\mathrm{CH}_{2} \mathrm{OAc}$

3, $\mathrm{X}=\mathrm{H}, \mathrm{Y}=\mathrm{CH}_{2} \mathrm{OH}$

Scheme 2. Preparation of benzo[e][1,2,4]triazines 1-3. Reagents and conditions: (i) 1-fluoro-2-nitro-5trifluoromethylbenzene, DMSO, $70{ }^{\circ} \mathrm{C}, 7 \mathrm{~h}$; (ii) 1 . Sn, glacial $\mathrm{AcOH}$, rt for $2 \mathrm{~h}$, then $115^{\circ} \mathrm{C}$ for $0.5 \mathrm{~h}$; 2. $\mathrm{NaIO}_{4}$; (iii) 1. Pd/C, $\mathrm{H}_{2}$, THF/EtOH, 2 days; 2. Air.

The requisite alcohols 1 and $\mathbf{3}$ and acetate 2 were obtained in two steps following an established general procedure $[57,63,64]$, as shown in Scheme 2 . Thus, the readily available benzhydrazides 5-7 were $\mathrm{N}$-arylated with 1-fluoro-2-nitro-5-trifluoromethylbenzene. The resulting hydrazides 8-10 were subsequently cyclized under reductive conditions (Sn powder $/ \mathrm{AcOH}$ ) followed by oxidation of the dihydro products with $\mathrm{Ag}_{2} \mathrm{O}$ or $\mathrm{NaIO}_{4}$ giving 
benzo[e][1,2,4]triazines $2-\mathbf{4}$ in good overall yields (40-75\%). Interestingly, during reductive cyclization of 9 at temperatures above $100{ }^{\circ} \mathrm{C}$, the hydroxymethyl group underwent esterification with $\mathrm{AcOH}$, used as the solvent and reagent in this reaction, and acetate 2 was isolated in $45 \%$ yield. The analogous acetate was not observed in the case of cyclization of hydrazide 10 conducted at ambient temperatures.

The hydroxyhexyloxy derivative $\mathbf{1}$ was obtained in $31 \%$ overall yield by Pd-catalyzed debenzylation of 4 , followed by aerial oxidation of the dihydro form. As noted above, debenzylation of 4 required longer-than-typical reaction times. The obtained hydroxy derivative 1 turned out to be sensitive to elevated temperatures: concentration of solutions of purified 1 on a rotavap at $40^{\circ} \mathrm{C}$ resulted in its decomposition and formation of a foulsmelling orange oil. Handling of $\mathbf{1}$ at lower temperatures avoided this problem, and pure product was obtained.

Benzhydrazides 5-7 were obtained by hydrazinolysis of the corresponding methyl benzoates with hydrazine hydrate.

\subsection{Synthesis of Tosylates and Phosphates}

Reactions of alcohols Ia-IIIa with tosyl chloride gave the desired tosylates Ib-IIIb in $82-96 \%$ yield (Scheme 3). The relatively high stability of Ib allowed for isolation of the pure compound using standard silica gel chromatography. In contrast, tosylates IIb and IIIb were sensitive to chromatography conditions and were used for the next step as crude materials.
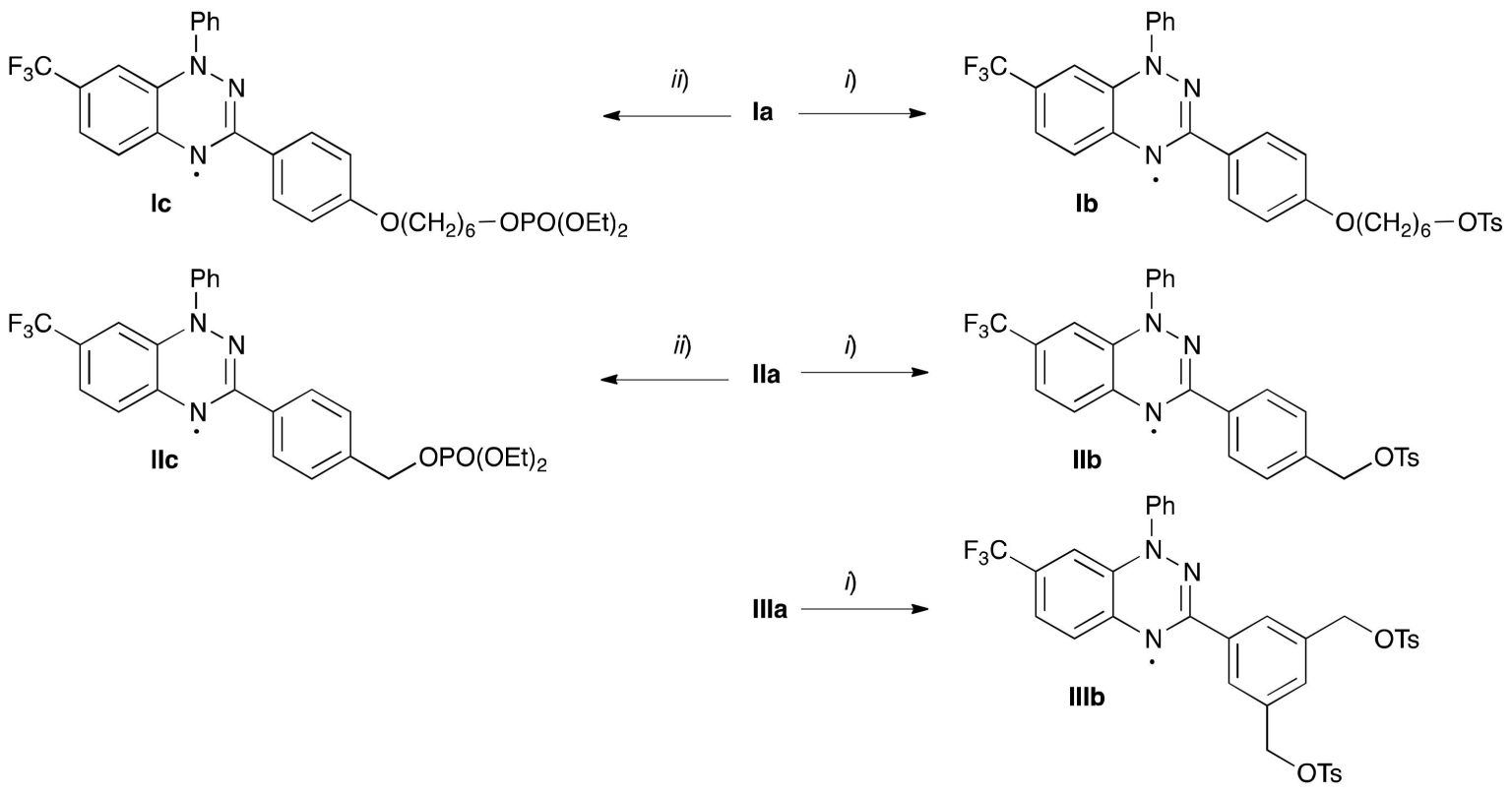

Scheme 3. Synthesis of tosylates Ib-IIIb and phosphates Ic and IIc. Reagents and conditions: (i) $\mathrm{TsCl}$, pyridine, $\mathrm{CH}_{2} \mathrm{Cl}_{2}$, rt, Ar, overnight, 82-96\% yield; (ii) (EtO) ${ }_{2} \mathrm{POCl}, \mathrm{DMAP}, \mathrm{Et} 3 \mathrm{~N}, \mathrm{THF}, \mathrm{rt}, 1 \mathrm{~h}, \mathrm{Ar}$, $83-86 \%$ yield.

Phosphorylation of alcohols Ia and IIa with diethyl chlorophosphate in the presence of DMAP and $\mathrm{Et}_{3} \mathrm{~N}$ gave the phosphates Ic and IIc, respectively, isolated in about $85 \%$ yield (Scheme 3).

\subsection{Transformation of Tosylates: Preparation of Disulfides and Azide}

Disulfides Id and IId were obtained in 18\% yield from tosylates Ib and IIb using a general procedure [65] involving reactions with the thiosulfate $\left(\mathrm{S}_{2} \mathrm{O}_{3}{ }^{2-}\right)$ nucleophile in DMSO, followed by oxidation of the resulting mercaptan with $\mathrm{I}_{2}$ (Scheme 4). 


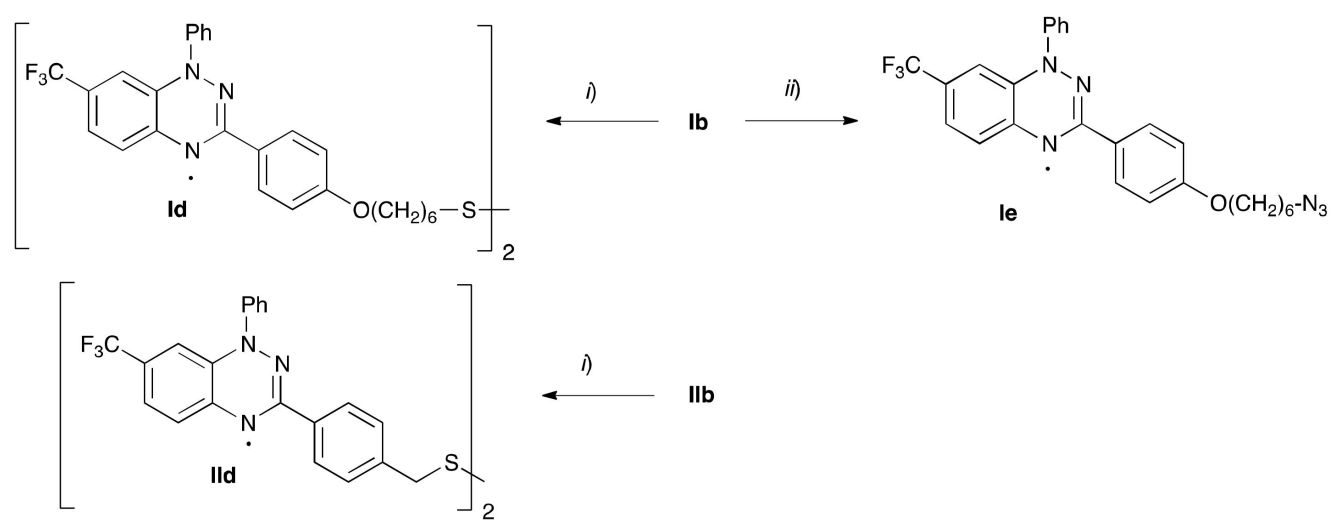

Scheme 4. Synthesis of disulfides Id and IId, and azide Ie. Reagents and conditions: (i) $1 . \mathrm{Na}_{2} \mathrm{~S}_{2} \mathrm{O}_{3}, \mathrm{DMSO}_{\text {, }}$ $60{ }^{\circ} \mathrm{C}$, overnight, 2. $\mathrm{I}_{2}, \mathrm{CH}_{2} \mathrm{Cl}_{2}, \mathrm{rt}, 10 \mathrm{~min}, 18 \%$ yield; (ii) $\mathrm{NaN}_{3}, \mathrm{DMF}, 50{ }^{\circ} \mathrm{C}, \mathrm{Ar}, 5 \mathrm{~h}, 42-73 \%$ yield.

In contrast, the preparation of azide Ie was straightforward and more efficient. Thus, reaction of toslyate $\mathbf{I b}$ with $\mathrm{NaN}_{3}$ in DMF gave azide Ie isolated in yields up to $73 \%$ yield (Scheme 4).

\subsection{Copper(I)-Catalyzed Azide-Alkyne Cycloaddition of Azide Ie}

Compound Ie represents the first azido derivative of the Blatter radical, and its suitability for the $\mathrm{Cu}(\mathrm{I})$-catalyzed cycloaddition reaction ("click") with alkynes, the CuAAC reaction, required experimental verification. Thus, the azide Ie was reacted with phenylacetylene in the presence of $\mathrm{Cu}(\mathrm{I})$, generated in situ from $\mathrm{CuSO}_{4}$ and sodium ascorbate, according to a general literature method [66]. The "click" product, $[1,2,3]$ triazole Ig, was isolated in a high yield of $84 \%$ (Scheme 5). This result compares to $53 \%$ yield of $[1,2,3]$ triazole formation in an analogous $\mathrm{CuAAC}$ reaction of acetylene-substituted Blatter radical $\mathbf{D}$ (Figure 1) with an azido derivative of norbornene [13].

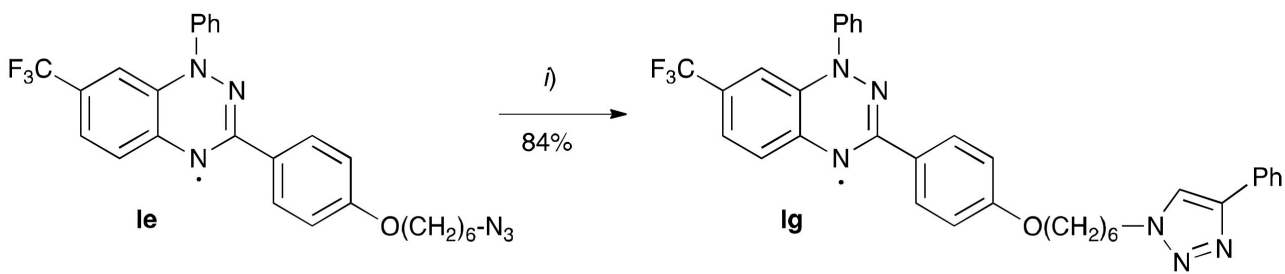

Scheme 5. Synthesis of Ig via azide-alkyne "click" reaction. Reagents and conditions: (i) Phenylacetylene, $\mathrm{CuSO}_{4} \cdot 5 \mathrm{H}_{2} \mathrm{O}$, sodium $L$-ascorbate, benzoic acid, $t-\mathrm{BuOH} / \mathrm{H}_{2} \mathrm{O} 1: 2$, rt, $5 \mathrm{~h}, 84 \%$ yield.

Pure Ig showed no decomposition during storage for 4 years under ambient conditions, according to thin-layer chromatography analysis.

\subsection{Spectroscopic Characterization of Radicals}

All radicals I-III exhibit low-intensity broad absorption in the entire visible range, as shown for Ia in Figure 3. Consequently, the compounds appear dark brown in solutions and nearly black in the solid state. EPR analysis of the radicals conducted in benzene solutions revealed seven principal lines resulting from hyperfine splitting with three ${ }^{14} \mathrm{~N}$ nuclei modulated with additional smaller splitting by ${ }^{19} \mathrm{~F}$ and ${ }^{1} \mathrm{H}$ nuclei, as shown for derivative Ia in Figure 3. For some radicals, the principal lines are less resolved, presumably due to aggregation in benzene solutions (see the Supplementary Materials). Analysis demonstrated that the $a_{\mathrm{N}} h f c c$ values for radicals I-III are consistent with those for other Blatter radical derivatives, and are about 7.6 G for $a_{\mathrm{N}(1)}$ and about $4.5-4.9 \mathrm{G}$ for $a_{\mathrm{N}(2)}$ and $a_{\mathrm{N}(4)}$. Simulation of the experimental spectra indicates that the $a_{\mathrm{F}} h f c c$ value is in a range of 3.2-3.6 G. 

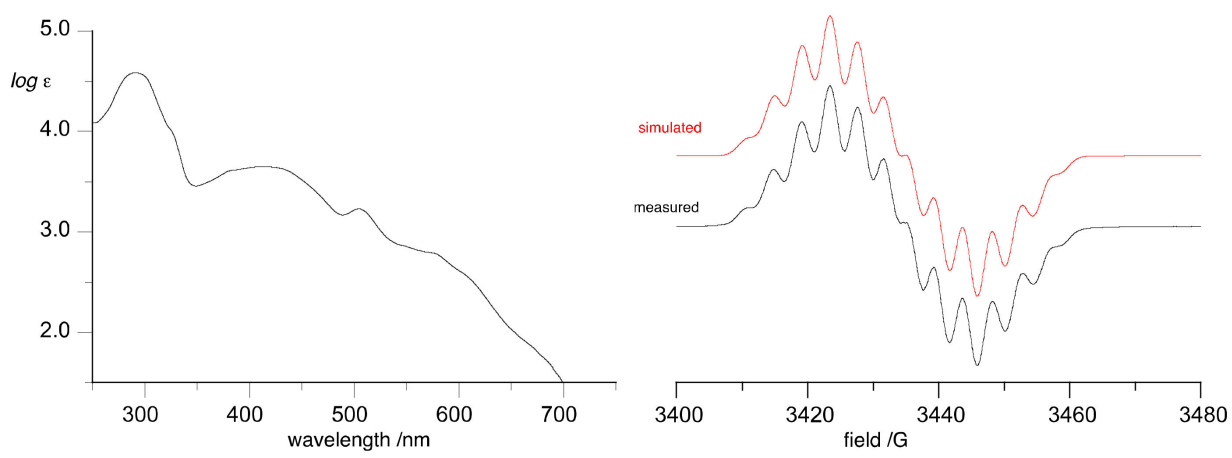

Figure 3. Electronic absorption spectrum in $\mathrm{CH}_{2} \mathrm{Cl}_{2}$ (left) and ERP spectrum in benzene (right) for Ia.

\section{Conclusions}

The "super stable" Blatter radical B was substituted at the $\mathrm{C}(3)$ phenyl ring with a long tether $\left(\mathrm{O}\left(\mathrm{CH}_{2}\right)_{6}-\mathrm{X}, \mathbf{I}\right)$, a short tether $\left(\mathrm{CH}_{2}-\mathrm{X}, \mathrm{II}\right)$ or two anchoring groups $\left(2 \times \mathrm{CH}_{2}-\right.$ $X$, III). The key intermediates contain the hydroxyl group $(X=\mathrm{OH}, \mathbf{a})$, which could be used for grafting in condensation (acylation) and addition (e.g., carbamination) reactions. The hydroxyl derivatives Ia-IIIa are efficiently converted to tosylates Ib-IIIb, which served as electrophilic intermediates to disulfides Id and IId (for chemisorption onto Au surfaces) and azide Ie (for the CuAAC reaction). Tosylates IIb and IIIb can additionally be exploited to attach the Blatter radical to hydroxyl-functionalized partners through the formation of benzyl-type ether linkages. Following prior work on the synthesis and supramolecular properties of cyclodextrin-xylylene hybrids [67-70], we have conducted preliminary experiments supporting the viability of such an approach, and the results will be published in due course.

The demonstration of efficient "click" reaction of azide Ie with $\mathrm{PhC} \equiv \mathrm{CH}$ paves the way to grafting radical $\mathbf{B}$ onto surfaces and macromolecules functionalized with terminal ethynyl groups. This method represents a more versatile approach to paramagnetic materials, since many macromolecules substituted with the propargyl group are available.

The presented results constitute a promising approach to novel paramagnetic polymers with high radical density, e.g., for polymer electrodes with high charge storage capacity and for high-density paramagnetic surfaces for spintronic applications. This work is continued in our laboratory.

\section{Materials and Methods}

General. Reagents and solvents were purchased and used as received. THF was dried over Na metal in the presence of benzophenone and distilled before use. Column chromatography was performed on silica gel. For separation of radicals silica gel was passivated by mixing with $\mathrm{CH}_{2} \mathrm{Cl}_{2}$ containing $2 \%$ of $\mathrm{Et}_{3} \mathrm{~N}$ and removal of the solvent to dryness (rotovap). Reported yields refer to analytically pure samples. NMR spectra were recorded with a Bruker AVIII 500 or 600 instrument. Chemical shifts are reported relative to solvent $\left(\mathrm{CDCl}_{3}\right)$ residual peaks $\left({ }^{1} \mathrm{H}\right.$ NMR: $\delta=7.26 \mathrm{ppm}$ and ${ }^{13} \mathrm{C}$ NMR: $\left.\delta=77.16 \mathrm{ppm}\right)[71]$. All ${ }^{13} \mathrm{C}$ NMR spectra are proton-decoupled. IR spectra were measured in $\mathrm{KBr}$ pellets with a FTIR NEXUS spectrometer. High-resolution mass spectrometry (HRMS) measurements were performed using SYNAPT G2-Si High-Definition Mass Spectrometry equipped with an ESI or APCI source and Quantitative Time-of-Flight (QuanTof) mass analyzer. Melting points were determined in capillaries with a MEL-TEMP II apparatus and are uncorrected. If not stated otherwise, reactions were carried out under argon atmosphere in flame-dried flasks with addition of the reactants via syringe. Subsequent manipulations were conducted in air.

EPR spectra of radicals I-III were recorded on an X-band EMX-Nano EPR spectrometer at ambient temperature using dilute and degassed solutions in distilled benzene in a concentration range of $2-5 \times 10^{-4} \mathrm{M}$. Additional details are shown in the SI. 
Preparation of radicals Ia-IIIa via PhLi addition to benzo[e][1,2,4]triazines 1-3. A general method. To a solution of the appropriate benzo[e][1,2,4]triazine derivative $\mathbf{1}, \mathbf{2}$, or $3(0.792 \mathrm{mmol})$ in dry THF $(10 \mathrm{~mL})$, PhLi (1.9 M in dibutyl ether, $1.24 \mathrm{~mL}, 2.360 \mathrm{mmol})$ was added dropwise at $-5{ }^{\circ} \mathrm{C}$ under argon and the reaction mixture was stirred at this temperature for $1 \mathrm{~h}$, then for $1 \mathrm{~h}$ at rt under air. Water was added and the product was extracted with $\mathrm{CH}_{2} \mathrm{Cl}_{2}(3 \times)$. The combined organic extracts were dried $\left(\mathrm{Na}_{2} \mathrm{SO}_{4}\right)$, and volatiles were removed on a rotavap. Pure product was isolated by column chromatography followed by recrystallization (MeCN).

1-Phenyl-3-[4-(6-hydroxyhexyloxy)phenyl]-7-trifluoromethyl-1,4-dihydrobenzo[e] [1,2,4]triazin-4-yl (Ia). Starting from triazine 1. Yield: $322 \mathrm{mg}$ (87-94\% range yield) of pure Ia as a brown solid: $\mathrm{mp} 145-146^{\circ} \mathrm{C}$; IR (KBr) v 3400, 2932, 2854, 1607, 1514, 1393, 1356, 1314, 1246, 1118, 1063, $841 \mathrm{~cm}^{-1}$; UV $\left(\mathrm{CH}_{2} \mathrm{Cl}_{2}\right) \lambda_{\max }(\log \varepsilon) 291$ (4.58), 413 (3.65), 504 (3.20) nm; EPR (benzene) $a_{N} 7.57,4.54,4.87, a_{F} 3.51 \mathrm{G}, g=2.0048$; HRMS (ESI-TOF) $[\mathrm{M}+\mathrm{H}]^{+} \mathrm{m} / z$ calcd for $\mathrm{C}_{26} \mathrm{H}_{26} \mathrm{~F}_{3} \mathrm{~N}_{3} \mathrm{O}_{2}$ : 469.1977; found: 469.1984. Anal. Calcd for $\mathrm{C}_{26} \mathrm{H}_{25} \mathrm{~F}_{3} \mathrm{~N}_{3} \mathrm{O}_{2}$ : C, 66.66; $\mathrm{H}$, 5.38; N, 8.97. Found: C, 66.46; H, 5.45; N, 8.77.

1-Phenyl-3-(4-hydroxymethylphenyl)-7-trifluoromethyl-1,4-dihydrobenzo[e][1,2,4] triazin-4-yl (IIa). Staring from triazine 2. The crude product was passed through a passivated silica gel plug (pet. ether/AcOEt 1:1) and recrystallized (MeCN) to give $279 \mathrm{mg}$ (92\% yield) of pure IIa as an olive solid: $\mathrm{mp} 204-205^{\circ} \mathrm{C}$; IR (KBr) $v$ 3366, 3275, 3054, 1592, 1489, 1397, 1355, 1315, 1265, 1166, 1117, 1062, 1013, $905 \mathrm{~cm}^{-1}$; EPR (benzene) $a_{N}$ 7.40, 4.59, 4.90, $a_{F} 3.24 \mathrm{G}, g=2.0034 ; \mathrm{HRMS}$ (ESI-TOF) $[\mathrm{M}+\mathrm{H}]^{+} m / z$ calcd for $\mathrm{C}_{21} \mathrm{H}_{16} \mathrm{~F}_{3} \mathrm{~N}_{3} \mathrm{O}: 383.1245$; found: 383.1233. Anal. Calcd for $\mathrm{C}_{21} \mathrm{H}_{15} \mathrm{~F}_{3} \mathrm{~N}_{3} \mathrm{O}$ : C, 65.97; $\mathrm{H}, 3.95 ; \mathrm{N}, 10.99$. Found: $\mathrm{C}, 66.10$; $\mathrm{H}, 4.06 ; \mathrm{N}, 11.25$.

1-Phenyl-3-[3,5-bis(hydroxymethyl)phenyl]-7-trifluoromethyl-1,4-dihydrobenzo[e] -[1,2,4]triazin-4-yl (IIIa). Starting from triazine 3 . The crude product was passed through a passivated silica gel plug (pet. ether/AcOEt 1:1) and recrystallized (MeCN) to give IIIa as

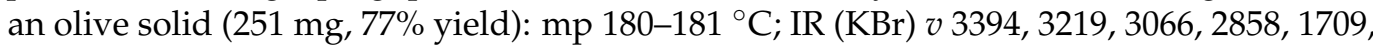
$1592,1490,1427,1396,1322,1278,1130,1070,875,841,765,692 \mathrm{~cm}^{-1}$; EPR (benzene) $a_{N} 7.64$, $4.60,4.79, a_{F} 3.49 \mathrm{G}, g=2.0038$; HRMS (ESI-TOF) $[\mathrm{M}+\mathrm{H}]^{+} m / z$ calcd for $\mathrm{C}_{22} \mathrm{H}_{18} \mathrm{~F}_{3} \mathrm{~N}_{3} \mathrm{O}_{2}$ : 413,1351; found: 413.1355.

Preparation of 1-phenyl-3-[4-(6-tosyloxyhexyloxy)phenyl]-7-trifluoromethyl-1,4-di -hydrobenzo[e][1,2,4]triazin-4-yl (Ib). To a solution of alcohol Ia (500 mg, $1.07 \mathrm{mmol})$ in dry $\mathrm{CH}_{2} \mathrm{Cl}_{2}(6 \mathrm{~mL})$, pyridine $(0.25 \mathrm{~mL}, 3.10 \mathrm{mmol})$ and tosyl chloride $(305 \mathrm{mg}, 1.60 \mathrm{mmol})$ were added and the reaction mixture was stirred at $\mathrm{rt}$ overnight under argon. The reaction mixture was washed with $\mathrm{H}_{2} \mathrm{O}$, brine and dried $\left(\mathrm{Na}_{2} \mathrm{SO}_{4}\right)$. Organic solvents were removed on a rotavap and the residue was passed through a silica gel plug $\left(\mathrm{CH}_{2} \mathrm{Cl}_{2} / \mathrm{EtOAc} 19: 1\right)$ to give $637 \mathrm{mg}$ (96\% yield) of pure tosylate Ib as a brown solid: $\mathrm{mp} 120-121{ }^{\circ} \mathrm{C}$; IR (KBr) $v$ 2940, 2864, 1605, 1390, 1355, 1316, 1244, 1172, 1119, 960, $842 \mathrm{~cm}^{-1}$; HRMS (ESI-TOF) [M+H] ${ }^{+}$ $m / z$ calcd for $\mathrm{C}_{33} \mathrm{H}_{32} \mathrm{~F}_{3} \mathrm{~N}_{3} \mathrm{O}_{4} \mathrm{~S}$ : 623.2066; found: 623.2062. Anal. Calcd for $\mathrm{C}_{33} \mathrm{H}_{31} \mathrm{~F}_{3} \mathrm{~N}_{3} \mathrm{O}_{4} \mathrm{~S}$ : C, 63.65; H, 5.02; N, 6.75; S, 5.15. Found: C, 63.65; H, 5.16; N, 6.63; S, 5.03.

Preparation of tosylates IIb and IIIb. A general method. To a solution of alcohol IIa or IIIa $(0.79 \mathrm{mmol})$ and tosyl chloride $(300 \mathrm{mg}, 1.57 \mathrm{mmol})$ in dry THF $(10 \mathrm{~mL}), 60 \% \mathrm{NaH}$ in mineral oil $(475 \mathrm{mg}, 11.85 \mathrm{mmol})$ was added in portions over $30 \mathrm{~min}$. The suspension was stirred at rt for another $30 \mathrm{~min}$, and water was added dropwise to neutralize the unreacted $\mathrm{NaH}$. The reaction mixture was extracted with $\mathrm{CH}_{2} \mathrm{Cl}_{2}(3 \times)$. The combined organic extracts were dried $\left(\mathrm{Na}_{2} \mathrm{SO}_{4}\right)$ and concentrated in vacuo. The crude product was passed through a silica gel plug passivated with $\mathrm{Et}_{3} \mathrm{~N}$ (pet ether/AcOEt 4:1) to give IIb or IIIb as green-brown solid. The product was immediately used for the next step without further purification

1-Phenyl-3-[4-(tosyloxymethyl)phenyl]-7-trifluoromethyl-1,4-dihydrobenzo[e][1,2,4] triazin-4-yl (IIb). Starting from IIa. Yield: $413 \mathrm{mg}$ (98\% yield) of IIb as a brown solid; HRMS (ESI-TOF) $[\mathrm{M}+\mathrm{H}]^{+} \mathrm{m} / z$ calcd for $\mathrm{C}_{28} \mathrm{H}_{22} \mathrm{~F}_{3} \mathrm{~N}_{3} \mathrm{O}_{3} \mathrm{~S}$ : 537.1334; found: 537.1330.

1-Phenyl-3-[3,5-bis(tosyloxymethyl)phenyl]-7-trifluoromethyl-1,4-dihydrobenzo[e] -[1,2,4]triazin-4-yl (IIIb). Starting from IIIa. Yield: $558 \mathrm{mg}$ (98\% yield) of IIIb as a 
brown solid; HRMS (ESI-TOF) $[\mathrm{M}+\mathrm{H}]^{+}$HRMS, $m / z$ calcd for $\mathrm{C}_{36} \mathrm{H}_{30} \mathrm{~F}_{3} \mathrm{~N}_{3} \mathrm{O}_{6} \mathrm{~S}_{2}: 721,1528$; found: 721.1536 .

Preparation of phosphates Ic and IIc. A general method. To a solution of alcohol Ia or IIa (0.2 mmol, 1.0 equiv.), DMAP ( $0.02 \mathrm{mmol}, 0.1$ equiv.) and $\mathrm{Et}_{3} \mathrm{~N}$ (1.0 mmol, 5 equiv.) dissolved in THF ( $2 \mathrm{~mL}$ ) diethyl chlorophosphate $(1.0 \mathrm{mmol}, 5$ equiv.) was added slowly via syringe. During the addition, a white precipitate formed. The reaction mixture was stirred at $\mathrm{rt}$ for $1 \mathrm{~h}$ until substrate was no longer present in the reaction mixture (TLC control). The reaction was quenched with sat. $\mathrm{NH}_{4} \mathrm{Cl}$ solution, extracted with $\mathrm{CH}_{2} \mathrm{Cl}_{2}$, and the product was purified by column chromatography (pet. ether/AcOEt 3:2).

1-Phenyl-3-[4-(6-diethoxyphosphoryloxyhexyloxy)phenyl]-7-trifluoromethyl-1,4-d -ihydrobenzo[e][1,2,4]triazin-4-yl (Ic). Starting from Ia. Yield: $103.9 \mathrm{mg}$ (86\% yield) of phosphate Ic as a soft waxy material; IR (KBr) $v 2925,2854,1607,1490,1399,1318,1248$, $1165,1108,1027,829,698 \mathrm{~cm}^{-1}$; EPR (benzene) $a_{N} 7.56,4.78,4.53, a_{F} 3.56 \mathrm{G}, g=2.0037$; HRMS (ESI-TOF) [M+H] $]^{+} m / z$ calcd for $\mathrm{C}_{30} \mathrm{H}_{35} \mathrm{~N}_{3} \mathrm{O}_{5} \mathrm{~F}_{3} \mathrm{P}: 605.2266$; found: 605.2273.

1-Phenyl-3-[4-(diethoxyphosphoryloxymethyl)phenyl]-7-trifluoromethyl-1,4-dihyd -robenzo[e][1,2,4]triazin-4-yl (IIc). Starting from IIa. Yield: $86.1 \mathrm{mg}$ (83\% yield) of phosphate IIc as a soft waxy material; IR (KBr) $v 2925,2854,1593,1492,1422,1323,1265,1166$, 1120, 1036, 824, $698 \mathrm{~cm}^{-1}$; EPR (benzene) $a_{N} 7.59,4.63,4.72, a_{F} 3.56 \mathrm{G} g=2.0046$; HRMS (ESI-TOF) $[\mathrm{M}+\mathrm{H}]^{+} \mathrm{m} / z$ calcd for $\mathrm{C}_{25} \mathrm{H}_{25} \mathrm{~N}_{3} \mathrm{O}_{4} \mathrm{~F}_{3} \mathrm{P}: 519.1535$; found: 519.1529 .

Preparation of disulfides Id and IId. A general method. A mixture of tosylate Ib or IIb $(0.64 \mathrm{mmol})$ and solid $\mathrm{Na}_{2} \mathrm{~S}_{2} \mathrm{O}_{3}(102 \mathrm{mg}, 0.64 \mathrm{mmol})$ in DMSO $(15 \mathrm{~mL})$ was stirred at $60{ }^{\circ} \mathrm{C}$ overnight. The reaction mixture was cooled to rt and extracted with $\mathrm{AcOEt}(3 \times)$. The combined organic extracts were dried $\left(\mathrm{Na}_{2} \mathrm{SO}_{4}\right)$ and concentrated in vacuo. The residue was dissolved in $\mathrm{CH}_{2} \mathrm{Cl}_{2}(10 \mathrm{~mL})$ and solid $\mathrm{I}_{2}(49 \mathrm{mg}, 0.19 \mathrm{mmol})$ was added and stirred at rt for $10 \mathrm{~min}$, filtered, the solid was washed with $\mathrm{CH}_{2} \mathrm{Cl}_{2}$ and the filtrate was evaporated. The crude product was passed through a passivated silica gel plug (pet. ether/AcOEt 5:1) and recrystallized (MeCN) to give pure product Id or IId as brown solids.

Disulfide Id. Starting from Ib. Yield: $55.0 \mathrm{mg}\left(18 \%\right.$ yield); $\mathrm{mp} 73^{\circ} \mathrm{C}$; IR (KBr) v 2936, $2855,1605,1512,1487,1426,1398,1319,1251,1170,1115,1060,840,695 \mathrm{~cm}^{-1} ; \mathrm{UV}\left(\mathrm{CH}_{2} \mathrm{Cl}_{2}\right)$ $\lambda_{\max }(\log \varepsilon) 292$ (4.82), 384 (4.01), 503 (3.34) nm; EPR (benzene) $a_{N} 7.32,4.66,4.55, a_{F} 3.32 \mathrm{G}$, $g=2.0038$; HRMS (ESI-TOF) [M] ${ }^{+} m / z$ calcd for $\mathrm{C}_{52} \mathrm{H}_{48} \mathrm{~F}_{6} \mathrm{~N}_{6} \mathrm{O}_{2} \mathrm{~S}_{2}$ : 966.3184; found: 966.3218 . Anal. Calcd for $\mathrm{C}_{52} \mathrm{H}_{48} \mathrm{~F}_{6} \mathrm{~N}_{6} \mathrm{O}_{2} \mathrm{~S}_{2}$ : C, 64.58; H, 5.00; N, 8.69; $\mathrm{S}$, 6.63. Found: $\mathrm{C}, 64.30 ; \mathrm{H}, 5.10$; N, 8.63; S, 6.84 .

Disulfide IId. Starting from IIb. Yield: $45.8 \mathrm{mg}\left(18 \%\right.$ yield); $\mathrm{mp} 170{ }^{\circ} \mathrm{C} ; \mathrm{IR}(\mathrm{KBr}) v$ 3073, 1592, 1488, 1397, 1316, 1264, 1116, 1062, 905, 844, 763, $693 \mathrm{~cm}^{-1}$; UV $\left(\mathrm{CH}_{2} \mathrm{Cl}_{2}\right) \lambda_{\max }$ $(\log \varepsilon) 284$ (4.89), 374 (4.04), 430 (3.78), 498 (3.42) nm; HRMS (ESI-TOF) [M] ${ }^{+} \mathrm{m} / z$ calcd for $\mathrm{C}_{42} \mathrm{H}_{28} \mathrm{~F}_{6} \mathrm{~N}_{6} \mathrm{~S}_{2}$ : 794.1721; found: 794.1726. Anal. Calcd for $\mathrm{C}_{42} \mathrm{H}_{28} \mathrm{~F}_{6} \mathrm{~N}_{6} \mathrm{~S}_{2}: \mathrm{C}, 63.47 ; \mathrm{H}, 3.55$; N, 10.57; S, 8.07. Found: C, 63.45; H, 3.61; N, 10.46; S, 8.05.

Preparation of 1-phenyl-3-[4-(6-azidohexyloxy)phenyl]-7-trifluoromethyl-1,4-dihyd -robenzo[e][1,2,4]triazin-4-yl (Ie). To a solution of tosylate $\mathbf{I b}(750 \mathrm{mg}, 1.204 \mathrm{mmol})$ in dry DMF (18 mL) sodium azide (391 $\mathrm{mg}, 6.02 \mathrm{mmol})$ was added in one portion and the reaction mixture was stirred for $5 \mathrm{~h}$ at $50{ }^{\circ} \mathrm{C}$ under argon. After the reaction is completed (no starting material detected by TLC), $\mathrm{H}_{2} \mathrm{O}$ and brine were added, and the product was extracted with $\mathrm{CH}_{2} \mathrm{Cl}_{2}(3 \times)$. The organic layer was washed with $\mathrm{H}_{2} \mathrm{O}(3 \times)$, then with brine, and dried $\left(\mathrm{Na}_{2} \mathrm{SO}_{4}\right)$. Solvents were removed and the residue was purified by column chromatography $\left(\mathrm{SiO}_{2}, \mathrm{CH}_{2} \mathrm{Cl}_{2} 100 \%\right)$ to give $432 \mathrm{mg}$ (73\% yield) of pure azide Ie as brown solid: $\mathrm{mp} 88-90^{\circ} \mathrm{C}$; IR (KBr) v 2939, 2857, $2098\left(\mathrm{~N}_{3}\right), 1606,1397,1354,1317,1247,1113 \mathrm{~cm}^{-1}$; EPR (benzene) $a_{N} 7.57,4.82,4.98, a_{F} 3.33 \mathrm{G}, g=2.0049 ;$ HRMS (ESI-TOF) $[\mathrm{M}+\mathrm{H}]^{+} \mathrm{m} / z$ calcd for $\mathrm{C}_{26} \mathrm{H}_{25} \mathrm{~F}_{3} \mathrm{~N}_{6} \mathrm{O}$ : 494.2042; found: 494.2031 .

Preparation of 1-phenyl-3-[4-(6-benzyloxyhexyloxy)phenyl]-7-trifluoromethyl -1,4dihydrobenzo[ $e][1,2,4]$ triazin-4-yl (If). Radical If was obtained in $44-64 \%$ yield by addition of $\mathrm{PhLi}$ to triazine $\mathbf{4}$ according to the general procedure for preparation of alcohol Ia-IIIa. The crude product was passed through a silica gel plug (pet. ether/Et ${ }_{2} \mathrm{O} 3: 2$ ) and recrystallized $(\mathrm{EtOH})$ to give pure If as a brown solid: $\mathrm{mp} 98-100{ }^{\circ} \mathrm{C}$; HRMS (ESI-TOF) [M] ${ }^{+}$ 
$m / z$ calcd for $\mathrm{C}_{33} \mathrm{H}_{31} \mathrm{~F}_{3} \mathrm{~N}_{3} \mathrm{O}_{2}$ : 558.2368; found: 558.2363. Anal. Calcd for $\mathrm{C}_{33} \mathrm{H}_{31} \mathrm{~F}_{3} \mathrm{~N}_{3} \mathrm{O}_{2}$ : C, 70.95; H, 5.59; N, 7.52. Found: C, 70.95; H, 5.56; N, 7.62.

Preparation of 1-phenyl-3-[4-(6-[1,2,3]triazolylhexyloxy)phenyl]-7-trifluoromethyl1,4-dihydrobenzo[e][1,2,4]triazin-4-yl (Ig). To a solution of $\mathrm{CuSO}_{4} \times 5 \mathrm{H}_{2} \mathrm{O}(\sim 3 \mathrm{mg})$, sodium ascorbate $(\sim 3 \mathrm{mg})$ and benzoic acid $(\sim 3 \mathrm{mg})$ in $t-\mathrm{BuOH} / \mathrm{H}_{2} \mathrm{O} 1: 2(4 \mathrm{~mL})$ a mixture of phenylacetylene $(20.0 \mathrm{mg}, 0.196 \mathrm{mmol})$ and azide Ie $(95.0 \mathrm{mg}, 0.192 \mathrm{mmol})$ was added at rt. The resulting mixture was stirred for $5 \mathrm{~h}$ (TLC monitoring, $\mathrm{CH}_{2} \mathrm{Cl}_{2}, \mathrm{R}_{\mathrm{f}}=0.08$ and 0.45 for product $\mathbf{I g}$ and azide Ie, respectively). $\mathrm{CH}_{2} \mathrm{Cl}_{2}$ was added and the organic phase was washed with $\mathrm{H}_{2} \mathrm{O}$ and brine and dried $\left(\mathrm{Na}_{2} \mathrm{SO}_{4}\right)$. Solvents were removed in vacuum and the product was purified by column chromatography $\left(\mathrm{SiO}_{2}, \mathrm{CH}_{2} \mathrm{Cl}_{2} 100 \%\right.$ gradient to $\left.\mathrm{CH}_{2} \mathrm{Cl}_{2} / \mathrm{EtOAc} 4: 1\right)$ to give $97 \mathrm{mg}$ (84\% yield) of pure triazole Ig as a brown solid: $\mathrm{mp}$ $160{ }^{\circ} \mathrm{C}$ dec.; IR (KBr) v 2943, 1607, 1400, 1357, 1319, 1246, 1121, 837, $\mathrm{cm}^{-1}$; UV $\left(\mathrm{CH}_{2} \mathrm{Cl}_{2}\right)$ $\lambda_{\max }(\log \varepsilon) 290$ (4.58), 411 (3.62), 504 (3.20) nm; EPR (benzene) $a_{N}$ 7.59, 4.73, 4.87, $a_{F} 3.50 \mathrm{G}$, $g=2.0054$; HRMS (ESI-TOF) $[\mathrm{M}+\mathrm{H}]^{+} \mathrm{m} / z$ calcd for $\mathrm{C}_{34} \mathrm{H}_{31} \mathrm{~F}_{3} \mathrm{~N}_{6} \mathrm{O}: 596.2511$; found: 596.2506 . Anal. Calcd for $\mathrm{C}_{34} \mathrm{H}_{30} \mathrm{~F}_{3} \mathrm{~N}_{6} \mathrm{O}$ : C, 68.56; H, 5.08; N, 14.11. Found: $\mathrm{C}, 68.59 ; \mathrm{H}, 5.00 ; \mathrm{N}, 13.97$.

Preparation of 3-[4-(6-hydroxyhexyloxy)phenyl]-7-trifluoromethylbenzo[e][1,2,4] triazine (1). A solution of benzyloxy derivative $4(3.00 \mathrm{~g} 6.23 \mathrm{mmol})$ in THF $(35 \mathrm{~mL})$ was added to a suspension of $5 \% \mathrm{Pd} / \mathrm{C}(2.60 \mathrm{~g})$ in $\mathrm{EtOH}(35 \mathrm{~mL})$, and the resulting mixture was hydrogenated (50 psi) overnight. The reaction mixture was passed through a Celite pad and oxidized by exposure to air (TLC monitoring) and the solvents were removed under reduced pressure (cold bath!). Crude product was purified by column chromatography $\left(\mathrm{SiO}_{2}, \mathrm{CH}_{2} \mathrm{Cl}_{2} /\right.$ EtOAc $\left.4: 1\right)$ to give $0.76 \mathrm{~g}$ ( $31 \%$ yield) of pure product 1 as a yellow solid: mp $144-145{ }^{\circ} \mathrm{C} ;{ }^{1} \mathrm{H}$ NMR $\left(600 \mathrm{MHz}, \mathrm{CDCl}_{3}\right) \delta 8.82(\mathrm{~s}, 1 \mathrm{H}), 8.74(\mathrm{~d}, J=8.9 \mathrm{~Hz}, 2 \mathrm{H}), 8.16(\mathrm{~d}$, $J=8.8 \mathrm{~Hz}, 1 \mathrm{H}), 8.08\left(\mathrm{dd}, J_{1}=8.9 \mathrm{~Hz}, J_{2}=1.9 \mathrm{~Hz}, 1 \mathrm{H}\right), 7.10(\mathrm{~d}, J=8.9 \mathrm{~Hz}, 2 \mathrm{H}), 4.11(\mathrm{t}, J=6.5 \mathrm{~Hz}$, $2 \mathrm{H}$ ), $3.69(\mathrm{t}, J=6.5 \mathrm{~Hz}, 2 \mathrm{H}), 1.87$ (quint, $J=7.0 \mathrm{~Hz}, 2 \mathrm{H}$ ), 1.64 (quint, $J=7.1 \mathrm{~Hz}, 2 \mathrm{H}$ ), 1.56 (quint, $J=7.5 \mathrm{~Hz}, 2 \mathrm{H}), 1.48$ (quint, $J=7.4 \mathrm{~Hz}, 2 \mathrm{H}), 1.25(\mathrm{~s}, 1 \mathrm{H}) ;{ }^{13} \mathrm{C}\left\{{ }^{1} \mathrm{H}\right\} \mathrm{NMR}(126 \mathrm{MHz}$, $\left.\mathrm{CDCl}_{3}\right) \delta 162.8,160.9,144.9,142.3,131.2(\mathrm{q}, J=34 \mathrm{~Hz}), 131.1,130.9(\mathrm{q}, J=3 \mathrm{~Hz}), 130.7,127.9$ $(\mathrm{q}, J=4 \mathrm{~Hz}) 127.3,123.3(\mathrm{q}, J=273 \mathrm{~Hz}), 115.1,68.2,63.0,32.8,29.3,26.0,25.7 ; \mathrm{IR}(\mathrm{KBr}) v 3297$, 2938, 2863, 1605, 1510, 1487, 1427, 1337, 1252, 1173, 1134, 1059, 1003, 908, 842, 699, $638 \mathrm{~cm}^{-1}$; HRMS (ESI-TOF) [M+H] $]^{+} m / z$ calcd for $\mathrm{C}_{20} \mathrm{H}_{21} \mathrm{~F}_{3} \mathrm{~N}_{3} \mathrm{O}_{2}$ : 392.1586; found: 392.1590. Anal. Calcd for $\mathrm{C}_{20} \mathrm{H}_{20} \mathrm{~F}_{3} \mathrm{~N}_{3} \mathrm{O}_{2}$ : C, 61.38; $\mathrm{H}, 5.15 ; \mathrm{N}, 10.74$. Found: $\mathrm{C}, 61.57 ; \mathrm{H}, 5.12 ; \mathrm{N}, 10.74$.

Preparation of triazines 2-4. A general method. To a solution of hydrazide 8, 9 or 10 (6.96 mmol) in glacial $\mathrm{AcOH}(100 \mathrm{~mL})$, Sn powder $(4.54 \mathrm{~g}, 38.3 \mathrm{mmol})$ was added and stirred at rt for $2 \mathrm{~h}$, and then at $115^{\circ} \mathrm{C}$ for $30 \mathrm{~min}$. After cooling, EtOAc and $\mathrm{H}_{2} \mathrm{O}$ were added, and the mixture was filtered through a Celite pad. The solution was extracted with two portions of EtOAc, and the combined organic extracts were washed with saturated aq. $\mathrm{NaHCO}_{3}(3 \times)$ and dried $\left(\mathrm{Na}_{2} \mathrm{SO}_{4}\right)$. Solvents were removed on a rotavap, and the residue was dissolved in a $\mathrm{CH}_{2} \mathrm{Cl}_{2} / \mathrm{MeOH}$ mixture (1:1) and solid $\mathrm{NaIO}_{4}(2.23 \mathrm{~g}, 10.44 \mathrm{mmol}$ ) or $\mathrm{Ag}_{2} \mathrm{O}$ (354 mg, $1.52 \mathrm{mmol}$ ) was added. The mixture was stirred at rt until complete consumption of the dihydro form. The solution was filtered, and the solvents were removed under reduced pressure. The crude product was purified on silica gel and recrystallized to give pure triazines $2-4$.

3-(4-Acetoxymethylphenyl)-7-trifluoromethylbenzo[ $[e][1,2,4]$ triazine (2). Starting from hydrazide 9 using modified method. The suspension was stirred at $70{ }^{\circ} \mathrm{C}$ overnight and at $120^{\circ} \mathrm{C}$ for $1 \mathrm{~h}$. Solid $\mathrm{Ag}_{2} \mathrm{O}$ was used for oxidation. The crude product was purified by column chromatography $\left(\mathrm{SiO}_{2}\right.$, pet. ether/ $\left.\mathrm{AcOEt} 4: 1\right)$ and further by recrystallization $\left(\mathrm{CH}_{2} \mathrm{Cl}_{2} / \mathrm{EtOH}\right)$ to give $967 \mathrm{mg}$ ( $40 \%$ yield) of triazine 2 as yellow crystals: $\mathrm{mp} 136-137^{\circ} \mathrm{C}$; ${ }^{1} \mathrm{H} \mathrm{NMR}\left(500 \mathrm{MHz}, \mathrm{CDCl}_{3}\right) 8.84(\mathrm{~s}, 1 \mathrm{H}), 8.76(\mathrm{~d}, J=8.3 \mathrm{~Hz}, 2 \mathrm{H}), 8.21(\mathrm{~d}, J=8.9 \mathrm{~Hz}, 1 \mathrm{H}), 8.11$ $\left(\mathrm{dd}, J_{1}=8.9 \mathrm{~Hz}, J_{2}=1.9 \mathrm{~Hz}, 1 \mathrm{H}\right), 7.58(\mathrm{~d}, J=8.4 \mathrm{~Hz}, 2 \mathrm{H}), 5.23(\mathrm{~s}, 2 \mathrm{H}), 2.16(\mathrm{~s}, 3 \mathrm{H}) .{ }^{13} \mathrm{C}\left\{{ }^{1} \mathrm{H}\right\}$ NMR (151 MHz, CDCl $\left.{ }_{3}\right) \delta 170.9,160.6,145.3,142.1,140.4,134.8,132.0(\mathrm{q}, J=34 \mathrm{~Hz}), 131.1$ $(\mathrm{q}, J=3 \mathrm{~Hz}), 131.0,129.5,128.7,128.0(\mathrm{q}, J=4 \mathrm{~Hz}), 123.2(\mathrm{q}, J=273 \mathrm{~Hz}), 65.8,21.1 ; \mathrm{IR}(\mathrm{KBr})$ v 3070, 1744, 1630, 1508, 1425, 1328, 1257, 1173, 1131, 1056, 1012, 901, 842, $641 \mathrm{~cm}^{-1}$; HRMS (AP-TOF) $[\mathrm{M}+\mathrm{H}]^{+} \mathrm{m} / z$ calcd for $\mathrm{C}_{17} \mathrm{H}_{13} \mathrm{~F}_{3} \mathrm{~N}_{3} \mathrm{O}_{2}$ : 348.0960; found: 348.0961. Anal. Calcd for $\mathrm{C}_{17} \mathrm{H}_{12} \mathrm{~F}_{3} \mathrm{~N}_{3} \mathrm{O}_{2}$ : C, 58,79; $\mathrm{H}, 3.48 ; \mathrm{N}, 12.10$. Found: $\mathrm{C}, 58.83 ; \mathrm{H}, 3.45 ; \mathrm{N}, 12.25$. 
3-[3,5-Bis(hydroxymethyl)phenyl]-7-trifluoromethylbenzo[e][1,2,4]triazine (3). Starting from hydrazide $\mathbf{1 0}$ using modified method. The suspension was stirred at rt overnight without further heating. Solid $\mathrm{Ag}_{2} \mathrm{O}$ was used for oxidation. The resulting crude product was purified by chromatography $\left(\mathrm{SiO}_{2}\right.$, pet. ether / AcOEt 1:1) and further by recrystallization (AcOEt) to give $1.28 \mathrm{~g}\left(40-55 \%\right.$ yield) of triazine 3 as yellow crystals: $\mathrm{mp} 174-175{ }^{\circ} \mathrm{C}$; ${ }^{1} \mathrm{H}$ NMR $\left(500 \mathrm{MHz}\right.$, DMSO-d $\left.d_{6}\right) \delta 9.02(\mathrm{~s}, 1 \mathrm{H}), 8.52(\mathrm{~s}, 2 \mathrm{H}), 8.37(\mathrm{~s}, 2 \mathrm{H}), 7.54(\mathrm{~s}, 1 \mathrm{H}), 5.43(\mathrm{t}$, $J=5.7 \mathrm{~Hz}, 2 \mathrm{H}), 4.66(\mathrm{~d}, J=5.6 \mathrm{~Hz}, 4 \mathrm{H}) ;{ }^{13} \mathrm{C}\left\{{ }^{1} \mathrm{H}\right\} \mathrm{NMR}\left(126 \mathrm{MHz}, \mathrm{DMSO}-d_{6}\right) \delta 160.1,145.0$, $143.6,141.7,134.3,131.4,131.2,130.3(q, J=33 \mathrm{~Hz}), 128.3,127.8,125.1,123.3(\mathrm{q}, J=273 \mathrm{~Hz})$, 63.2; IR (KBr) v 3270, 3180, 2945, 2884, 1627, 1509, 1421, 1330, 1236, 1214, 1167, 1121, 1055, 1021, 846, $664 \mathrm{~cm}^{-1}$; HRMS (ESI-TOF) $[\mathrm{M}+\mathrm{H}]^{+} \mathrm{m} / z$ calcd for $\mathrm{C}_{16} \mathrm{H}_{13} \mathrm{~F}_{3} \mathrm{~N}_{3} \mathrm{O}_{2}$ : 336,0960; found: 336.0964. Anal. Calcd for $\mathrm{C}_{16} \mathrm{H}_{12} \mathrm{~F}_{3} \mathrm{~N}_{3} \mathrm{O}_{2}$ : $\mathrm{C}, 57.32 ; \mathrm{H}, 3.61 ; \mathrm{N}, 12.53$. Found: $\mathrm{C}$, 57.39; H, 3.58; N, 12.62.

Preparation of 3-[4-(6-benzyloxyhexyloxy)phenyl]-7-trifluoromethylbenzo[e][1,2,4] triazine (4). Starting from 8 using general method. The crude product was purified on column chromatography $\left(\mathrm{SiO}_{2}, \mathrm{CH}_{2} \mathrm{Cl}_{2} 100 \%\right)$ to give $2.50 \mathrm{~g}$ (75\% yield) of pure triazine 4 as an orange solid: $\mathrm{mp} 109-110{ }^{\circ} \mathrm{C} ;{ }^{1} \mathrm{H}$ NMR $\left(500 \mathrm{MHz}, \mathrm{CDCl}_{3}\right) \delta 8.80(\mathrm{~s}, 1 \mathrm{H}), 8.71(\mathrm{~d}$, $J=8.9 \mathrm{~Hz}, 2 \mathrm{H}), 8.14(\mathrm{~d}, J=8.9 \mathrm{~Hz}, 1 \mathrm{H}), 8.06\left(\mathrm{dd}, J_{1}=8.9 \mathrm{~Hz}, J_{2}=1.7 \mathrm{~Hz}, 1 \mathrm{H}\right), 7.35$ $(\mathrm{d}, J=4.4 \mathrm{~Hz}, 4 \mathrm{H}), 7.30-7.27(\mathrm{~m}, 1 \mathrm{H}), 7.07(\mathrm{~d}, J=8.9 \mathrm{~Hz}, 2 \mathrm{H}), 4.52(\mathrm{~s}, 2 \mathrm{H}), 4.08(\mathrm{t}$, $J=6.5 \mathrm{~Hz}, 2 \mathrm{H}), 3.51(\mathrm{t}, J=6.5 \mathrm{~Hz}, 2 \mathrm{H}), 1.86$ (quint, $J=6.9 \mathrm{~Hz}, 2 \mathrm{H}$ ), 1.68 (quint, $J=7.0 \mathrm{~Hz}, 2 \mathrm{H}), 1.53-1.49(\mathrm{~m}, 4 \mathrm{H}) ;{ }^{13} \mathrm{C}\left\{{ }^{1} \mathrm{H}\right\} \mathrm{NMR}\left(126 \mathrm{MHz}, \mathrm{CDCl}_{3}\right) \delta 162.8,160.9,144.8$, 142.3, 138.7, $131.2(\mathrm{q}, J=34 \mathrm{~Hz}), 131.1,130.8(\mathrm{q}, J=2 \mathrm{~Hz}), 130.7,128.5,127.9(\mathrm{q}, J=3 \mathrm{~Hz})$, $127.8,127.6,127.2,123.3(\mathrm{q}, J=273), 115.1,73.0,70.4,68.3,29.8,29.3,26.1,26.0$; IR $(\mathrm{KBr})$ v 2939, 2849, 1603, 1509, 1426, 1322, 1258, 1178, 1128, 1089, 1055, 977, $842 \mathrm{~cm}^{-1}$; HRMS (ESI-TOF) $[\mathrm{M}+\mathrm{H}]^{+} \mathrm{m} / z$ calcd for $\mathrm{C}_{27} \mathrm{H}_{27} \mathrm{~F}_{3} \mathrm{~N}_{3} \mathrm{O}_{2}$ : 482.2055; found: 482.2050. Anal. Calcd for $\mathrm{C}_{27} \mathrm{H}_{26} \mathrm{~F}_{3} \mathrm{~N}_{3} \mathrm{O}_{2}$ : C, 67.35; $\mathrm{H}, 5.44 ; \mathrm{N}$, 8.73. Found: $\mathrm{C}, 67.32 ; \mathrm{H}, 5.56 ; \mathrm{N}, 8.50$.

Preparation of hydrazides 5-7. A general method. The solution of methyl benzoate derivative $(4.00 \mathrm{~g}, 24.0 \mathrm{mmol})$ and hydrazine monohydrate $(8.0 \mathrm{~mL})$ in EtOH $(100 \mathrm{~mL})$ was refluxed for $48 \mathrm{~h}$. The reaction mixture was cooled and concentrated in vacuo. Crude hydrazides 6 and 7 were recrystallized from hot EtOH to give pure products as white crystals. The crude hydrazide 5 was dissolved in EtOAc, washed with $\mathrm{H}_{2} \mathrm{O}$ and dried $\left(\mathrm{Na}_{2} \mathrm{SO}_{4}\right)$. Solvents were removed on rotavap, and the product was purified by column chromatography $\left(\mathrm{SiO}_{2}, \mathrm{CH}_{2} \mathrm{Cl}_{2} /\right.$ EtOAc 4:1 gradient to 1:3).

4-(6-Benzyloxyhexyloxy)benzhydrazide (5). Yield: $5.43 \mathrm{~g}$ (70\% yield) of pure product 5 as a colorless solid: $\mathrm{mp} 88-89{ }^{\circ} \mathrm{C} ;{ }^{1} \mathrm{H}$ NMR $\left(500 \mathrm{MHz}, \mathrm{DMSO}-d_{6}\right) \delta 9.61(\mathrm{~s}, 1 \mathrm{H}), 7.78(\mathrm{~d}$, $J=8.8 \mathrm{~Hz}, 2 \mathrm{H}), 7.35-7.30(\mathrm{~m}, 4 \mathrm{H}), 7.27(\mathrm{t}, J=6.9 \mathrm{~Hz}, 1 \mathrm{H}), 6.95(\mathrm{~d}, J=8.8 \mathrm{~Hz}, 2 \mathrm{H}), 4.44(\mathrm{~s}$, $4 \mathrm{H}$ ), $3.99(\mathrm{t}, J=6.5 \mathrm{~Hz}, 2 \mathrm{H}), 3.42(\mathrm{t}, J=6.5 \mathrm{~Hz}, 2 \mathrm{H}), 1.70$ (quint, $J=6.8 \mathrm{~Hz}, 2 \mathrm{H}$ ), 1.55 (quint, $J=6.8 \mathrm{~Hz}, 2 \mathrm{H}), 1.44-1.34(\mathrm{~m}, 4 \mathrm{H}) ;{ }^{13} \mathrm{C}\left\{{ }^{1} \mathrm{H}\right\} \mathrm{NMR}\left(126 \mathrm{MHz}, \mathrm{DMSO}-d_{6}\right) \delta 165.6,160.9,138.7$, $128.7,128.2,127.4,127.3,125.3,114.0,71.8,69.5,67.6,29.2,28.6,25.5,25.3$; IR (KBr) v 3321, 2940, 2852, 2796, 1618, 1605, 1536, 1500, 1455, 1341, 1258, 1175, 1127, 1105, 1026, 942, 846, $740 \mathrm{~cm}^{-1}$; HRMS (ESI-TOF) $[\mathrm{M}+\mathrm{H}]^{+} \mathrm{m} / \mathrm{z}$ calcd for $\mathrm{C}_{20} \mathrm{H}_{27} \mathrm{~N}_{2} \mathrm{O}_{3}$ : 343.2022; found: 343.2027 . Anal. Calcd for $\mathrm{C}_{20} \mathrm{H}_{26} \mathrm{~N}_{2} \mathrm{O}_{3}$ : C, 70.15; $\mathrm{H}, 7.65 ; \mathrm{N}, 8.18$. Found: $\mathrm{C}, 70.10 ; \mathrm{H}, 7.60 ; \mathrm{N}, 8.36$.

4-Hydroxymethylbenzhydrazide (6). Yield: $3.80 \mathrm{~g}$ (95\% yield) of $\mathbf{6}$ as colorless crystals: ${ }^{1} \mathrm{H}$ NMR $\left(500 \mathrm{MHz}, \mathrm{DMSO}-d_{6}\right) \delta 9.73(\mathrm{~s}, 1 \mathrm{H}), 7.78(\mathrm{~d}, J=8.3 \mathrm{~Hz}, 2 \mathrm{H}), 7.37(\mathrm{~d}, J=8.4 \mathrm{~Hz}$, $2 \mathrm{H}), 5.30(\mathrm{t}, J=5.7 \mathrm{~Hz}, 1 \mathrm{H}), 4.54(\mathrm{~d}, J=5.2 \mathrm{~Hz}, 2 \mathrm{H}), 4.48(\mathrm{~s}, 2 \mathrm{H}) ;{ }^{13} \mathrm{C}\left\{{ }^{1} \mathrm{H}\right\} \mathrm{NMR}(126 \mathrm{MHz}$, DMSO- $\left.d_{6}\right) \delta 166.0,145.8,131.7,126.9,126.1,62.5$; HRMS (ESI-TOF) $[\mathrm{M}+\mathrm{H}]^{+} \mathrm{m} / \mathrm{z}$ calcd for $\mathrm{C}_{8} \mathrm{H}_{11} \mathrm{~N}_{2} \mathrm{O}_{2}$ : 167.0821; found: 167.0821. Anal. Cald for $\mathrm{C}_{8} \mathrm{H}_{10} \mathrm{~N}_{2} \mathrm{O}_{2}: \mathrm{C}, 57.82 ; \mathrm{H}, 6.07 ; \mathrm{N}$, 16.86. Found: C, 57.84; H, 6.04; N, 16.89 .

3,5-Bis(hydroxymethyl)benzhydrazide (7). Yield: $4.24 \mathrm{~g}$ (90\% yield) of 7 as colorless crystals: mp $173-174{ }^{\circ} \mathrm{C} ;{ }^{1} \mathrm{H}$ NMR $\left(500 \mathrm{MHz}, \mathrm{DMSO}-d_{6}\right) \delta 9.72(\mathrm{~s}, 1 \mathrm{H}), 7.63(\mathrm{~s}, 2 \mathrm{H})$, $7.42(\mathrm{~s}, 1 \mathrm{H}), 5.28(\mathrm{t}, J=5.7 \mathrm{~Hz}, 2 \mathrm{H}), 4.52(\mathrm{~d}, J=5.4 \mathrm{~Hz}, 4 \mathrm{H}), 4.48(\mathrm{~s}, 2 \mathrm{H}) ;{ }^{13} \mathrm{C}\left\{{ }^{1} \mathrm{H}\right\} \mathrm{NMR}$ $\left(126 \mathrm{MHz}, \mathrm{DMSO}-d_{6}\right) \delta 166.2,142.5,133.1,127.2,123.6,62.8$; IR (KBr) $v 3263,3149,3051$, 2929, 2872, 2783, 2664, 1638, 1536, 1460, 1355, 1260, 1156, 1045, 874, $704 \mathrm{~cm}^{-1}$; HRMS (ESI-TOF) $[\mathrm{M}+\mathrm{H}]^{+} \mathrm{m} / z$ calcd for $\mathrm{C}_{9} \mathrm{H}_{13} \mathrm{~N}_{2} \mathrm{O}_{3}$ : 197.0926; found: 197.0930. Anal. Calcd for $\mathrm{C}_{9} \mathrm{H}_{12} \mathrm{~N}_{2} \mathrm{O}_{3}$ : C, 55.09; $\mathrm{H}, 6.16 ; \mathrm{N}, 14.28$. Found: C, 55.08; $\mathrm{H}, 6.11 ; \mathrm{N}, 14.03$. 
Preparation of hydrazides 8-10. A general method. To a solution of substituted benzhydrazide 5-7 (8.76 mmol) in dry DMSO $(20 \mathrm{~mL})$, 1-fluoro-2-nitro-5-trifluoromethylbenzene $(1.83 \mathrm{~g}, 8.76 \mathrm{mmol})$ was added, and the reaction mixture was stirred at $70{ }^{\circ} \mathrm{C}$ overnight. The solution was cooled to $\mathrm{rt}$ and poured into a large amount of $\mathrm{H}_{2} \mathrm{O}$ and extracted with EtOAc. The organic layer was separated, washed with $\mathrm{H}_{2} \mathrm{O}(3 \mathrm{x})$, then with brine, and dried $\left(\mathrm{Na}_{2} \mathrm{SO}_{4}\right)$. Solvents were removed under vacuum and the crude product was recrystallized twice from EtOH to give corresponding pure hydrazide 5-7 as an orange solid.

$N$-(2-nitro-5-trifluoromethylbenzene)-4-(6-benzyloxyhexyloxy) benzhydrazide (8). From hydrazide 5. Yield: $3.85 \mathrm{~g}$ (83\% yield) of 8 as an orange solid: $\mathrm{mp} 115-116{ }^{\circ} \mathrm{C}$; ${ }^{1} \mathrm{H}$ NMR (500 MHz, DMSO- $\left.d_{6}\right) \delta 10.74(\mathrm{~s}, 1 \mathrm{H}), 9.69(\mathrm{~s}, 1 \mathrm{H}), 8.32(\mathrm{~d}, J=8.8 \mathrm{~Hz}, 1 \mathrm{H}), 7.92$ $(\mathrm{d}, J=8.8 \mathrm{~Hz}, 2 \mathrm{H}), 7.34-7.30(\mathrm{~m}, 5 \mathrm{H}), 7.27(\mathrm{t}, J=6.8 \mathrm{~Hz}, 1 \mathrm{H}), 7.17\left(\mathrm{dd}, J_{1}=8.8 \mathrm{~Hz}, J_{2}=1.6 \mathrm{~Hz}\right.$, $1 \mathrm{H}), 7.06(\mathrm{~d}, J=8.8 \mathrm{~Hz}, 2 \mathrm{H}), 4.44(\mathrm{~s}, 2 \mathrm{H}), 4.04(\mathrm{t}, J=6.4 \mathrm{~Hz}, 2 \mathrm{H}), 3.43(\mathrm{t}, J=6.4 \mathrm{~Hz}, 2 \mathrm{H})$, 1.74 (quint, $J=6.8 \mathrm{~Hz}, 2 \mathrm{H}), 1.57$ (quint, $J=6.8 \mathrm{~Hz}, 2 \mathrm{H}), 1.46-1.36(\mathrm{~m}, 4 \mathrm{H}) ;{ }^{13} \mathrm{C}\left\{{ }^{1} \mathrm{H}\right\} \mathrm{NMR}$ $\left(126 \mathrm{MHz}, \mathrm{DMSO}-d_{6}\right) \delta 165.7,161.9,145.3,138.8,135.2(\mathrm{q}, J=32 \mathrm{~Hz}), 133.5,129.5,128.2$, $127.9,127.4,127.3,123.9,123.1(q, J=274 \mathrm{~Hz}), 114.4,113.4,111.8,71.8,69.6,67.8,29.2,28.5$, 25.5, 25.3; IR (KBr) v 3319, 3253, 2933, 2854, 1642, 1607, 1540, 1493, 1436, 1339, 1297, 1256, $1227,1174,1128,937,892,844,765,731,697 \mathrm{~cm}^{-1}$; HRMS (ESI-TOF) $[\mathrm{M}+\mathrm{H}]^{+} \mathrm{m} / z$ calcd for $\mathrm{C}_{27} \mathrm{H}_{29} \mathrm{~F}_{3} \mathrm{~N}_{3} \mathrm{O}_{5}$ : 532.2059; found: 532.2062. Anal. Calcd for $\mathrm{C}_{27} \mathrm{H}_{28} \mathrm{~F}_{3} \mathrm{~N}_{3} \mathrm{O}_{5}: \mathrm{C}, 61.01 ; \mathrm{H}$, 5.31; N, 7.91. Found: C, 61.01; H, 5.36; N, 8.14.

$N^{\prime}$-(4-(hydroxymethyl)phenyl)-2-nitro-5-(trifluoromethyl) benzhydrazide (9). From hydrazide 6. Yield: $3.05 \mathrm{~g}$ (98\% yield) of 9 as yellow crystals: $\mathrm{mp} 189-190{ }^{\circ} \mathrm{C} ;{ }^{1} \mathrm{H} \mathrm{NMR}(500 \mathrm{MHz}$, DMSO- $\left._{6}\right) \delta 10.86(\mathrm{~s}, 1 \mathrm{H}), 9.72(\mathrm{~s}, 1 \mathrm{H}), 8.32(\mathrm{~d}, J=8.8 \mathrm{~Hz}, 1 \mathrm{H}), 7.92(\mathrm{~d}, J=8.3 \mathrm{~Hz}, 2 \mathrm{H}), 7.49$ $(\mathrm{d}, J=8.3 \mathrm{~Hz}, 2 \mathrm{H}), 7.35(\mathrm{~d}, J=1.2 \mathrm{~Hz}, 1 \mathrm{H}), 7.18\left(\mathrm{dd}, J_{1}=8.8 \mathrm{~Hz}, J_{2}=1.8 \mathrm{~Hz}, 1 \mathrm{H}\right), 5.37(\mathrm{t}$, $J=5.7 \mathrm{~Hz}, 1 \mathrm{H}), 4.59(\mathrm{~d}, J=5.7 \mathrm{~Hz}, 2 \mathrm{H}) ;{ }^{13} \mathrm{C}\left\{{ }^{1} \mathrm{H}\right\} \mathrm{NMR}\left(126 \mathrm{MHz}, \mathrm{DMSO}-d_{6}\right) \delta 166.2,147.2$, $145.2,135.2(\mathrm{q}, J=32 \mathrm{~Hz}), 133.6,130.3,127.9,127.4,126.4,123.1$ (q, $J=273 \mathrm{~Hz}), 113.4,111.8$, 62.4; IR (KBr) v 3325, 3256, 1648, 1594, 1536, 1492, 1339, 1263, 1228, 1190, 1127, 1056, 935, 831, $763 \mathrm{~cm}^{-1}$; HRMS (ESI-TOF) $[\mathrm{M}+\mathrm{H}]^{+} \mathrm{m} / z$ calcd for $\mathrm{C}_{15} \mathrm{H}_{13} \mathrm{~F}_{3} \mathrm{~N}_{3} \mathrm{O}_{4}$ : 356.0858; found: 356.0849. Anal. Calcd for $\mathrm{C}_{15} \mathrm{H}_{12} \mathrm{~F}_{3} \mathrm{~N}_{3} \mathrm{O}_{4}$ : C, 50.71; $\mathrm{H}, 3.40 ; \mathrm{N}, 11.83$. Found: $\mathrm{C}, 50.78 ; \mathrm{H}$, 3.39; N, 12.00 .

$N^{\prime}$-(3,5-bis(hydroxymethyl)phenyl)-2-nitro-5-(trifluoromethyl)benzohydrazide (10). From hydrazide 7. Yield: $3.04 \mathrm{~g}$ (90\% yield) of $\mathbf{1 0}$ as yellow crystals: mp $195-196{ }^{\circ} \mathrm{C} ;{ }^{1} \mathrm{H}$ NMR (500 MHz, DMSO- $\left.d_{6}\right) \delta 10.89(\mathrm{~s}, 1 \mathrm{H}), 9.73(\mathrm{~s}, 1 \mathrm{H}), 8.33$ (d, J = 8.6 Hz, 1H), 7.79 (s, 2H), $7.53(\mathrm{~s}, 1 \mathrm{H}), 7.33(\mathrm{~d}, J=1.1 \mathrm{~Hz}, 1 \mathrm{H}), 7.17\left(\mathrm{dd}, J_{1}=8.9 \mathrm{~Hz}, J_{2}=1.7 \mathrm{~Hz}, 1 \mathrm{H}\right), 5.37(\mathrm{t}$, $J=5.7 \mathrm{~Hz}, 2 \mathrm{H}), 4.59(\mathrm{~d}, J=5.6 \mathrm{~Hz}, 4 \mathrm{H}) ;{ }^{13} \mathrm{C}\left\{{ }^{1} \mathrm{H}\right\} \mathrm{NMR}\left(126 \mathrm{MHz}, \mathrm{DMSO}-d_{6}\right) \delta 166.5,145.2$, 143.0, $135.2(q, J=32 \mathrm{~Hz}), 133.6,131.8,128.2,128.0,123.9,123.2(q, J=273 \mathrm{~Hz}), 113.4,111.7$, 62.6; IR (KBr) v 3260, 2952, 1648, 1590, 1489, 1339, 1263, 1182, 1130, 1057, 987, 882; HRMS (ESI-TOF) $[\mathrm{M}+\mathrm{H}]^{+} \mathrm{m} / \mathrm{z}$ calcd for $\mathrm{C}_{16} \mathrm{H}_{15} \mathrm{~F}_{3} \mathrm{~N}_{3} \mathrm{O}_{5}$ : 386,0964; found: 386.0962. Anal. Calcd for $\mathrm{C}_{16} \mathrm{H}_{14} \mathrm{~F}_{3} \mathrm{~N}_{3} \mathrm{O}_{5}$ : C, 49.88; H, 3.66; N, 10.91. Found: $\mathrm{C}, 49.90 ; \mathrm{H}, 3.47 ; \mathrm{N}, 11.04$.

Supplementary Materials: The following are available online: NMR $\left({ }^{1} \mathrm{H}\right.$ and ${ }^{13} \mathrm{C}\left\{{ }^{1} \mathrm{H}\right\}$; Figures S1S18), UV (Figures S19-S22) and EPR spectra (Figures S23-S30). The supporting information can be downloaded.

Author Contributions: Conceptualization, P.K. and J.M.G.F.; methodology and analysis, S.K., B.A. and P.B.; writing —original draft preparation, S.K.; writing—review and editing, P.K., P.B. and J.M.G.F.; supervision, P.K. and J.M.G.F.; funding acquisition, P.K. and J.M.G.F. All authors have read and agreed to the published version of the manuscript.

Funding: This work was financially supported by the Foundation for Polish Science (TEAM/20163/24), MCIN/AEI/10.13039/501100011033, “ERDF A way of making Europe" (RTI2018-097609-BC21), and the Junta de Andalucía (P20_00166) and COST Action (CA18132-46179).

Institutional Review Board Statement: Not applicable.

Informed Consent Statement: Not applicable.

Data Availability Statement: Data obtained in this project are contained within this article and available upon request from the Authors. 
Conflicts of Interest: The authors declare no conflict of interest.

Sample Availability: Samples of the compounds are not available from the authors.

\section{References}

1. Giaconi, N.; Sorrentino, A.L.L.; Poggini, L.; Lupi, M.; Polewczyk, V.; Vinai, G.; Torelli, P.; Magnani, A.; Sessoli, R.; Menichetti, S.; et al. Stabilization of an Enantiopure Sub-Monolayer of Helicene Radical Cations on a Au(111) Surface through Noncovalent Interactions. Angew. Chem. Int. Ed. 2021, 60, 15276-15280. [CrossRef] [PubMed]

2. Poggini, L.; Lunghi, A.; Collauto, A.; Barbon, A.; Armelao, L.; Magnani, A.; Caneschi, A.; Totti, F.; Sorace, L.; Mannini, M. Chemisorption of nitronyl-nitroxide radicals on gold surface: An assessment of morphology, exchange interaction and decoherence time. Nanoscale 2021, 13, 7613-7621. [CrossRef] [PubMed]

3. Mas-Torrent, M.; Crivillers, N.; Mugnaini, V.; Ratera, I.; Rovira, C.; Veciana, J. Organic radicals on surfaces: Towards molecular spintronics. J. Mater. Chem. 2009, 19, 1691-1695. [CrossRef]

4. Mas-Torrent, M.; Crivillers, N.; Rovira, C.; Veciana, J. Attaching Persistent Organic Free Radicals to Surfaces: How and Why. Chem. Rev. 2011, 112, 2506-2527. [CrossRef]

5. Casu, M.B. Nanoscale Studies of Organic Radicals: Surface, Interface, and Spinterface. Accounts Chem. Res. 2018, 51, 753-760. [CrossRef]

6. Poggini, L.; Cucinotta, G.; Sorace, L.; Caneschi, A.; Gatteschi, D.; Sessoli, R.; Mannini, M. Nitronyl nitroxide radicals at the interface: A hybrid architecture for spintronics. Rendiconti Lince 2018, 29, 623-630. [CrossRef]

7. Junghoefer, T.; Nowik-Boltyk, E.M.; de Sousa, J.A.; Giangrisostomi, E.; Ovsyannikov, R.; Chassé, T.; Veciana, J.; Mas-Torrent, M.; Rovira, C.; Crivillers, N.; et al. Stability of radical-functionalized gold surfaces by self-assembly and on-surface chemistry. Chem. Sci. 2020, 11, 9162-9172. [CrossRef]

8. Ajayakumar, M.R.; Alcón, I.; Bromley, S.T.; Veciana, J.; Rovira, C.; Mas-Torrent, M. Direct covalent grafting of an organic radical core on gold and silver. RSC Adv. 2017, 7, 20076-20083. [CrossRef]

9. Ajayakumar, M.R.; Moreno, C.; Alcón, I.; Illas, F.; Rovira, C.; Veciana, J.; Bromley, S.T.; Mugarza, A.; Mas-Torrent, M. Neutral Organic Radical Formation by Chemisorption on Metal Surfaces. J. Phys. Chem. Lett. 2020, 11, 3897-3904. [CrossRef]

10. Mukherjee, S.; Boudouris, B.W. Organic Radical Polymers: New Avenues in Organic Electronics; Springer: Berlin/Heidelberg, Germany, 2017.

11. Tomlinson, E.P.; Hay, M.E.; Boudouris, B.W. Radical Polymers and Their Application to Organic Electronic Devices. Macromolecules 2014, 47, 6145-6158. [CrossRef]

12. Friebe, C.; Schubert, U.S. High-Power-Density Organic Radical Batteries. Top. Curr. Chem. Collect. 2019, 375, 65-99. [CrossRef]

13. Saal, A.; Friebe, C.; Schubert, U.S. Polymeric Blatter's radical via CuAAC and ROMP. Macromol. Chem. Phys. 2021, 222, 2100194. [CrossRef]

14. Zhang, K.; Monteiro, M.J.; Jia, Z. Stable organic radical polymers: Synthesis and applications. Polym. Chem. 2016, 7, 5589-5614. [CrossRef]

15. Pinto, L.F.; Lloveras, V.; Zhang, S.; Liko, F.; Veciana, J.; Muñoz-Gómez, J.L.; Vidal-Gancedo, J. Fully Water-Soluble Polyphosphorhydrazone-Based Radical Dendrimers Functionalized with Tyr-PROXYL Radicals as Metal-Free MRI T1 Contrast Agents. ACS Appl. Bio. Mater. 2020, 3, 369-376. [CrossRef]

16. Ali, B.M.; Velavan, B.; Sudhandiran, G.; Sridevi, J.; Nasar, A.S. Radical dendrimers: Synthesis, anti-tumor activity and enhanced cytoprotective performance of TEMPO free radical functionalized polyurethane dendrimers. Eur. Polym. J. 2020, $122,109354$. [CrossRef]

17. Badetti, E.; Lloveras, V.; Muñoz-Gómez, J.L.; Sebastián, R.M.; Caminade, A.M.; Majoral, J.P.; Veciana, J.; Vidal-Gancedo, J. Radical dendrimers: A family of five generations of phosphorus dendrimers functionalized with TEMPO radicals. Macromolecules 2014, 47,7717-7724. [CrossRef]

18. Yordanov, A.T.; Yamada, K.-I.; Krishna, M.C.; Mitchell, J.B.; Woller, E.; Cloninger, M.; Brechbiel, M.W. Spin-Labeled Dendrimers in EPR Imaging with Low Molecular Weight Nitroxides. Angew. Chem. Int. Ed. 2001, 40, 2690-2692. [CrossRef]

19. Mezzina, E.; Manoni, R.; Romano, F.; Lucarini, M. Spin-Labelling of Host-Guest Assemblies with Nitroxide Radicals. Asian J. Org. Chem. 2015, 4, 296-310. [CrossRef]

20. Casati, C.; Franchi, P.; Pievo, R.; Mezzina, E.; Lucarini, M. Unraveling Unidirectional Threading of $\alpha$-Cyclodextrin in a [2]Rotaxane through Spin Labeling Approach. J. Am. Chem. Soc. 2012, 134, 19108-19117. [CrossRef]

21. Franchi, P.; Fanì, M.; Mezzina, E.; Lucarini, M. Increasing the Persistency of Stable Free-Radicals: Synthesis and Characterization of a Nitroxide Based [1]Rotaxane. Org. Lett. 2008, 10, 1901-1904. [CrossRef]

22. Chechik, V.; Ionita, G. Bis spin-labelled cyclodextrins. New J. Chem. 2007, 31, 1726-1729. [CrossRef]

23. Beejapur, H.A.; Campisciano, V.; Franchi, P.; Lucarini, M.; Giacalone, F.; Gruttadauria, M. Fullerene as a Platform for Recyclable TEMPO Organocatalysts for the Oxidation of Alcohols. ChemCatChem 2014, 6, 2419-2424. [CrossRef]

24. Yang, C.; Guenzi, M.; Cicogna, F.; Gambarotti, C.; Filippone, G.; Pinzino, C.; Passaglia, E.; Dintcheva, N.T.; Carroccio, S.; Coiai, S. Grafting of polymer chains on the surface of carbon nanotubes via nitroxide radical coupling reaction. Polym. Int. 2016, 65, 48-56. [CrossRef] 
25. Tucker-Schwartz, A.K.; Garrell, R.L. Simple Preparation and Application of TEMPO-Coated $\mathrm{Fe}_{3} \mathrm{O}_{4}$ Superparamagnetic Nanoparticles for Selective Oxidation of Alcohols. Chem. A Eur. J. 2010, 16, 12718-12726. [CrossRef]

26. Zawada, K.; Tomaszewski, W.; Megiel, E. A smart synthesis of gold/polystyrene core-shell nanohybrids using TEMPO coated nanoparticles. RSC Adv. 2014, 4, 23876-23885. [CrossRef]

27. Hata, K.; Fujihara, H. Preparation and electrochemical polymerization of new multifunctional pyrrolethiolate-stabilized gold and palladium nanoparticles. Chem. Commun. 2002, 2714-2715. [CrossRef]

28. Caragheorgheopol, A.; Chechik, V. Mechanistic aspects of ligand exchange in Au nanoparticles. Phys. Chem. Chem. Phys. 2008, 10, 5029-5041. [CrossRef]

29. Schätz, A.; Grass, R.N.; Stark, W.J.; Reiser, O. TEMPO Supported on Magnetic C/Co-Nanoparticles: A Highly Active and Recyclable Organocatalyst. Chem. A Eur. J. 2008, 14, 8262-8266. [CrossRef]

30. Gozdziewska, M.; Cichowicz, G.; Markowska, K.; Zawada, K.; Megiel, E. Nitroxide-coated silver nanoparticles: Synthesis, surface physicochemistry and antibacterial activity. RSC Adv. 2015, 5, 58403-58415. [CrossRef]

31. Megiel, E. Surface modification using TEMPO and its derivatives. Adv. Colloid Interface Sci. 2017, 250, 158-184. [CrossRef]

32. Hansen, K.-A.; Blinco, J.P. Nitroxide radical polymers-A versatile material class for high-tech applications. Polym. Chem. 2018, 9 , 1479-1516. [CrossRef]

33. Ji, Y.; Long, L.; Zheng, Y. Recent advances of stable Blatter radicals: Synthesis, properties and applications. Mater. Chem. Front. 2020, 4, 3433-3443. [CrossRef]

34. Oyaizu, K.; Nishide, H. Radical Polymers for Organic Electronic Devices: A Radical Departure from Conjugated Polymers? Adv. Mater. 2009, 21, 2339-2344. [CrossRef]

35. Rajca, A.; Wang, Y.; Boska, M.; Paletta, J.T.; Olankitwanit, A.; Swanson, M.A.; Mitchell, D.G.; Eaton, S.S.; Eaton, G.R.; Rajca, S. Organic Radical Contrast Agents for Magnetic Resonance Imaging. J. Am. Chem. Soc. 2012, 134, 15724-15727. [CrossRef] [PubMed]

36. Francese, G.; Dunand, F.A.; Loosli, C.; Decurtins, S. Functionalization of PAMAM dendrimers with nitronyl nitroxide radicals as models for the outer-sphere relaxation in dentritic potential MRI contrast agents. Org. Magn. Reson. 2003, 41, 81-83. [CrossRef]

37. Wilcox, D.A.; Agarkar, V.V.; Mukherjee, S.; Boudouris, B.W. Stable Radical Materials for Energy Applications. Annu. Rev. Chem. Biomol. Eng. 2018, 9, 83-103. [CrossRef]

38. Suga, T.; Nishide, H. Stable Radicals: Fundamentals and Applied Aspects of Odd-Electron Compounds; Hicks, R.G., Ed.; Wiley \& Sons Ltd.: Chichester, UK, 2010; pp. 507-519.

39. Nevers, D.R.; Brushett, F.R.; Wheeler, D.R. Engineering radical polymer electrodes for electrochemical energy storage. J. Power Sources 2017, 352, 226-244. [CrossRef]

40. Almubayedh, S.; Chahma, M. Electrosynthesis and characterization of stable radical-functionalized oligo/polythiophenes. N. J. Chem. 2015, 39, 7738-7741. [CrossRef]

41. Low, J.Z.; Kladnik, G.; Patera, L.L.; Sokolov, S.; Lovat, G.; Kumarasamy, E.; Repp, J.; Campos, L.M.; Cvetko, D.; Morgante, A.; et al. The Environment-Dependent Behavior of the Blatter Radical at the Metal-Molecule Interface. Nano Lett. 2019, 19, 2543-2548. [CrossRef]

42. De Sousa, J.A.; Bejarano, F.; Gutiérrez, D.; Leroux, Y.R.; Nowik-Boltyk, E.M.; Junghoefer, T.; Giangrisostomi, E.; Ovsyannikov, R.; Casu, M.B.; Veciana, J.; et al. Exploiting the versatile alkyne-based chemistry for expanding the applications of a stable triphenylmethyl organic radical on surfaces. Chem. Sci. 2020, 11, 516-524. [CrossRef]

43. Ruthstein, S.; Artzi, R.; Goldfarb, D.; Naaman, R. EPR studies on the organization of self-assembled spin-labeled organic monolayers adsorbed on GaAs. Phys. Chem. Chem. Phys. 2005, 7, 524-529. [CrossRef]

44. Glosz, K.; Stolarczyk, A.; Jarosz, T. Siloxanes-Versatile Materials for Surface Functionalisation and Graft Copolymers. Int. J. Mol. Sci. 2020, 21, 6387. [CrossRef]

45. Fu, H.; Policarpio, D.M.; Batteas, J.D.; Bergbreiter, D.E. Redox-controlled 'smart' polyacrylamide solubility. Polym. Chem. 2010, 1 , 631-633. [CrossRef]

46. Schattling, P.; Jochum, F.D.; Theato, P. Multi-responsive copolymers: Using thermo-, light- and redox stimuli as three independent inputs towards polymeric information processing. Chem. Commun. 2011, 47, 8859-8861. [CrossRef]

47. Binder, W.H.; Sachsenhofer, R. 'Click' chemistry in polymer and material science: An update. Macromol. Rapid Commun. 2008, 29, 952-981. [CrossRef]

48. Johnson, J.A.; Finn, M.G.; Koberstein, J.T.; Turro, N.J. Construction of Linear Polymers, Dendrimers, Networks, and Other Polymeric Architectures by Copper-Catalyzed Azide-Alkyne Cycloaddition "Click" Chemistry. Macromol. Rapid Commun. 2008, 29, 1421. [CrossRef]

49. Le Droumaguet, B.; Velonia, K. Click Chemistry: A Powerful Tool to Create Polymer-Based Macromolecular Chimeras. Macromol. Rapid Commun. 2008, 29, 1073-1089. [CrossRef]

50. Kunz, T.K.; Wolf, M.O. Electrodeposition and properties of TEMPO functionalized polythiophene thin films. Polym. Chem. 2011, 2, 640-644. [CrossRef]

51. Rogers, F.J.M.; Norcott, P.L.; Coote, M.L. Recent advances in the chemistry of benzo[e][1,2,4]triazinyl radicals. Org. Biomol. Chem. 2020, 18, 8255-8277. [CrossRef]

52. Blatter, H.M.; Lukaszewski, H. A new stable free radical. Tetrahedron Lett. 1968, 9, 2701-2705. [CrossRef] 
53. Karecla, G.; Papagiorgis, P.; Panagi, N.; Zissimou, G.A.; Constantinides, C.P.; Koutentis, P.A.; Itskos, G.; Hayes, S.C. Emission from the stable Blatter radical. N. J. Chem. 2017, 41, 8604-8613. [CrossRef]

54. Constantinides, C.P.; Koutentis, P.A.; Krassos, H.; Rawson, J.M.; Tasiopoulos, A.J. Characterization and Magnetic Properties of a "Super Stable" Radical 1,3-Diphenyl-7-trifluoromethyl-1,4-dihydro-1,2,4-benzotriazin-4-yl. J. Org. Chem. 2011, 76, 2798-2806. [CrossRef]

55. Jasiński, M.; Szczytko, J.; Pociecha, D.; Monobe, H.; Kaszyński, P. Substituent-Dependent Magnetic Behavior of Discotic Benzo[e][1,2,4]triazinyls. J. Am. Chem. Soc. 2016, 138, 9421-9424. [CrossRef]

56. Jasiński, M.; Szymańska, K.; Gardias, A.; Pociecha, D.; Monobe, H.; Szczytko, J.; Kaszyński, P. Tuning the Magnetic Properties of Columnar Benzo[e][1,2,4]triazin-4-yls with the Molecular Shape. ChemPhysChem 2019, 20, 636-644. [CrossRef]

57. Shivakumar, K.I.; Pociecha, D.; Szczytko, J.; Kapuściński, S.; Monobe, H.; Kaszyński, P. Photoconductive bent-core liquid crystalline radicals with a paramagnetic polar switchable phase. J. Mater. Chem. C 2020, 8, 1083-1088. [CrossRef]

58. Zheng, Y.; Miao, M.-S.; Kemei, M.C.; Seshadri, R.; Wudl, F. The Pyreno-Triazinyl Radical-Magnetic and Sensor Properties. Isr. J. Chem. 2014, 54, 774-778. [CrossRef]

59. Zheng, Y.; Miao, M.-S.; Dantelle, G.; Eisenmenger, N.D.; Wu, G.; Yavuz, I.; Chabinyc, M.L.; Houk, K.N.; Wudl, F. A Solid-State Effect Responsible for an Organic Quintet State at Room Temperature and Ambient Pressure. Adv. Mater. 2015, 27, 1718-1723. [CrossRef]

60. Ciccullo, F.; Calzolari, A.; Bader, K.; Neugebauer, P.; Gallagher, N.M.; Rajca, A.; van Slageren, J.; Casu, M.B. Interfacing a Potential Purely Organic Molecular Quantum Bit with a Real-Life Surface. ACS Appl. Mater. Interfaces 2018, 11, 1571-1578. [CrossRef]

61. Ciccullo, F.; Gallagher, N.M.; Geladari, O.; Chasse, T.; Rajca, A.; Casu, M.B. A Derivative of the Blatter Radical as a Potential Metal-Free Magnet for Stable Thin Films and Interfaces. ACS Appl. Mater. Interfaces 2016, 8, 1805-1812. [CrossRef]

62. Poryvaev, A.S.; Gjuzi, E.; Polyukhov, D.M.; Hoffmann, F.; Fröba, M.; Fedin, M.V. Blatter radical-grafted mesoporous silica as prospective nanoplatform for spin manipulation at ambient conditions. Angew. Chem. Int. Ed. 2021, 60, 8683-8688. [CrossRef]

63. Constantinides, C.P.; Obijalska, E.; Kaszyński, P. Access to 1,4-dihydrobenzo[e][1,2,4]triazin-4-yl derivtives. Org. Lett. 2016, 18, 916-919. [CrossRef] [PubMed]

64. Kaszyński, P.; Constantinides, C.P.; Young, V.G., Jr. The Planar Blatter Radical: Structural Chemistry of 1,4-Dihydrobenzo[e][1,2,4] -triazin-4-yls. Angew. Chem. Int. Ed. 2016, 55, 11149-11152. [CrossRef] [PubMed]

65. Abbasi, M.; Mohammadizadeh, M.R.; Saeedi, N. The synthesis of symmetrical disulfides by reacting organic halides with Na2S2O3.5H2O in DMSO. N. J. Chem. 2016, 40, 89-92. [CrossRef]

66. Shao, C.; Wang, X.; Xu, J.; Zhao, J.; Zhang, Q.; Hu, Y. Carboxylic Acid-Promoted Copper(I)-Catalyzed Azide-Alkyne Cycloaddition. J. Org. Chem. 2010, 75, 7002-7005. [CrossRef]

67. Neva, T.; Carmona, T.; Benito, J.M.; Przybylski, C.; Mellet, C.O.; Mendicuti, F.; Fernández, J.M.G. Dynamic Control of the Self-Assembling Properties of Cyclodextrins by the Interplay of Aromatic and Host-Guest Interactions. Front. Chem. $2019,7,72$. [CrossRef]

68. Neva, T.; Ortiz Mellet, C.; García Fernández, J.M.; Benito, J.M. Multiply-linked cyclodextrin-aromatic hybrids: Caps, hinges and clips. J. Carbohydr. Chem. 2019, 38, 470-493. [CrossRef]

69. Neva, T.; Carbajo-Gordillo, A.I.; Benito, J.M.; Lana, H.; Marcelo, G.; Mellet, C.O.; De Ilarduya, C.T.; Mendicuti, F.; Fernández, J.M.G. Tuning the Topological Landscape of DNA-Cyclodextrin Nanocomplexes by Molecular Design. Chem. A Eur. J. 2020, 26, 15259-15269. [CrossRef]

70. Balbuena, P.; Lesur, D.; Álvarez, M.J.G.; Mendicuti, F.; Mellet, C.O.; Fernández, J.M.G. One-pot regioselective synthesis of 2I,3I-O-(o-xylylene)-capped cyclomaltooligosaccharides: Tailoring the topology and supramolecular properties of cyclodextrins. Chem. Commun. 2007, 3270-3272. [CrossRef]

71. Fulmer, G.R.; Miller, A.J.M.; Sherden, N.H.; Gottlieb, H.E.; Nudelman, A.; Stoltz, B.M.; Bercaw, J.E.; Goldberg, K.I. NMR Chemical Shifts of Trace Impurities: Common Laboratory Solvents, Organics, and Gases in Deuterated Solvents Relevant to the Organometallic Chemist. Organometallics 2010, 29, 2176-2179. [CrossRef] 